\title{
Present Conditions and Future Challenges of Water Resources Problems in Iraq
}

\author{
Nadhir Al-Ansari, Ammar A. Ali, Sven Knutsson \\ Department of Civil, Environmental and Natural Resources Engineering, Lulea University of Technology, Lulea, \\ Sweden \\ Email: nadhir.alansari@ltu.se, ammar.ali@ltu.se, sven.kuntsson@ltu.se
}

Received 18 July 2014; revised 12 August 2014; accepted 1 September 2014

Copyright (C) 2014 by authors and Scientific Research Publishing Inc.

This work is licensed under the Creative Commons Attribution International License (CC BY).

http://creativecommons.org/licenses/by/4.0/

c) (i) Open Access

\begin{abstract}
Iraq is part of the Middle East and North Africa (MENA region). It greatly relies in its water resources on the Tigris and Euphrates Rivers. Iraq was considered rich in its water resources till 1970s. After that problems due to water scarcity aroused. Recently, it is expected that water shortage problems will be more serious. The supply and demand are predicted to be 43 and 66.8 Billion Cubic Meters (BCM) respectively in 2015, while in 2025 it will be 17.61 and 77BCM respectively. In addition, future prediction suggests that Tigris and Euphrates Rivers will be completely dry in 2040. To overcome this problem, prudent water management plan is to be adopted. It should include Strategic Water Management Vision, development of irrigation techniques, reduction of water losses, use of non-conventional water resources and research and development planning.
\end{abstract}

\section{Keywords}

Iraq, Tigris River, Euphrates River, Water Scarcity, Water Resources Management

\section{Introduction}

Iraq is part of the Middle East and North Africa (MENA region). It covers an area of 433,970 square kilometers populated by about 32 million inhabitants (Figure 1) [1] [2]. This region is characterized by its water shortage problem [1]-[6] where at least 12 countries have acute water scarcity problems with less than $500 \mathrm{~m}^{3}$ of renewable water resources per capita available [7] [8]. The supply of fresh water is essential to life, socioeconomic development, and political stability in this region. It was reported that one cubic meter of water can provide drinking water for one person for one year and the same quantity can produce only one kg of food grain when used for irrigation in a dry climate [9]. The largest consumer of water across the region is agriculture where it accounts for $66 \%$ of demand [5] [10] and therefore the water shortage problem cannot be objectively analysed nor adequately 


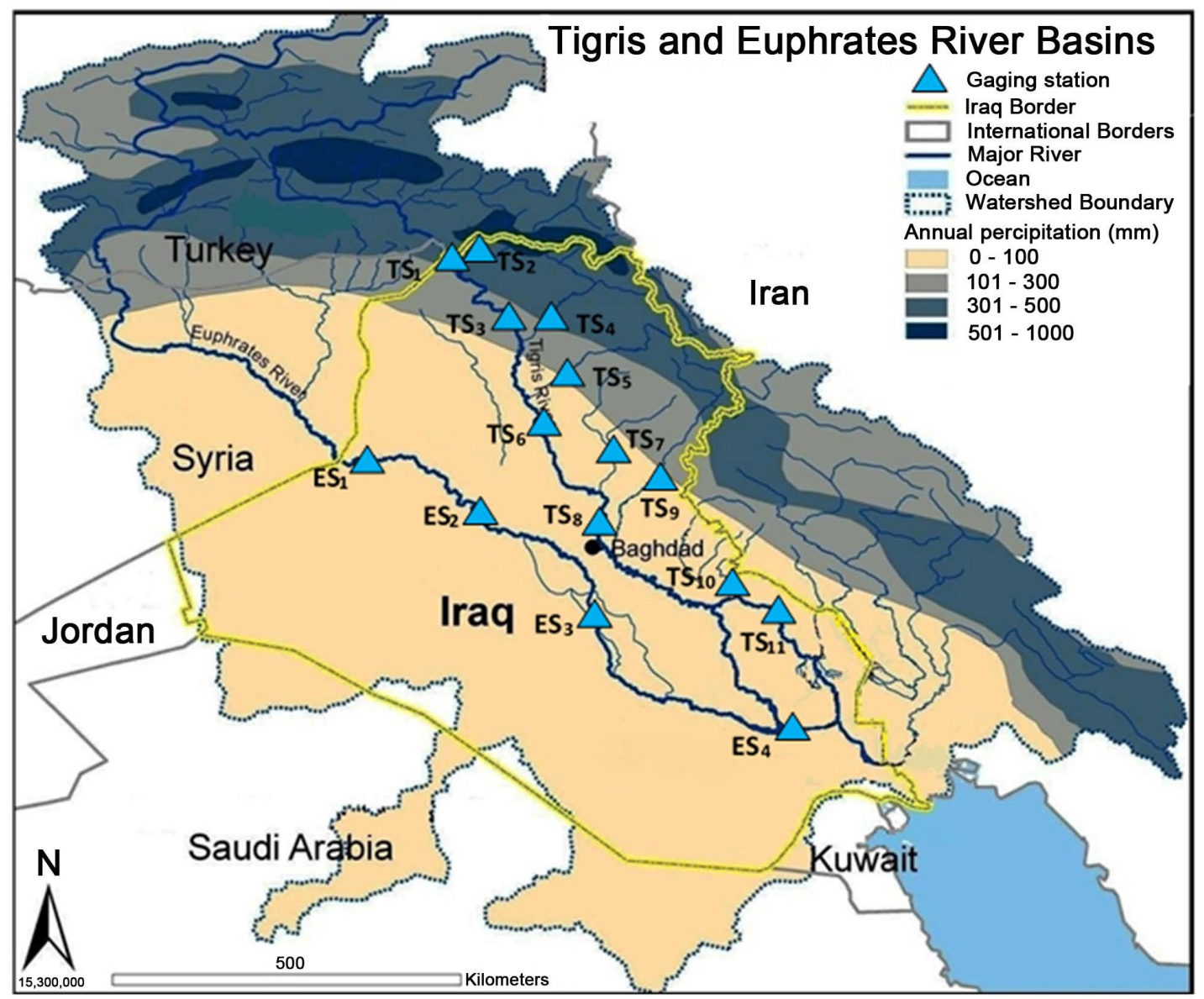

Figure 1. Physiography of Iraq.

addressed without a thorough consideration of agriculture [11]. If we consider $10 \%$ transfer of water away from agriculture would produce a 40\% increase in domestic water supply for Jordan [11]. Postel [12] argues that rather than diverting precious water to agriculture this water could be saved by importing the food/grain. However, this is not the case in many Middle Eastern countries which have unrealistic aspirations of food self-sufficiency and it would require a most fundamental change in national outlook [13]. Sadik and Barghouti [11] emphasized that the extent of the problem is so severe that "the future challenges in meeting the growing demands for water are beyond the capabilities of individual countries”. Mitigating supply shortfalls could be achieved by re-allocation of current agricultural supplies [3]. Future predictions suggest more shortages [14]-[16] and depletion of groundwater resources [2] [17] [18].

Iraq is bordered by Turkey from the north, $352 \mathrm{~km}$, Iran from the east, $1458 \mathrm{~km}$, Syria and Syria from the west, $605 \mathrm{~km}$ and $181 \mathrm{~km}$, respectively and Saudi Arabia and Kuwait from the south, $814 \mathrm{~km}$ and $240 \mathrm{~km}$ respectively (Figure 1). Topographically, Iraq is divided into 4 regions (Figure 1). The mountain region occupies 5\% of the total area of Iraq, restricted at the north and north eastern part of the country. This region is part of Taurus-Zagrus mountain range. Plateau and Hills Regions is the second region and it represents $15 \%$ of the total area of Iraq. This region is bordered by the mountainous region at the north and the Mesopotamian plain from the south. The Mesopotamian plain is the third region and it is restricted between the main two Rivers, Tigris and Euphrates. It occupies $20 \%$ of the total area of Iraq. This plain extends from north at Samara, on the Tigris, to Hit, on the Euphrates, toward the Gulf in the south. The remainder area of Iraq which forms $60 \%$ of the total area is referred to as the Jazera and Western Plateau.

Iraq was considered rich in its water resources compared with other countries where the annual allocation per capita reached $6029 \mathrm{~m}^{3}$ in 1995 and expected to be $2100 \mathrm{~m}^{3}$ in 2015 [19]. Construction of dams on the Tigris and Euphrates and their tributaries outside the border of Iraq, the effect of global climate change and mismanagement 
of water resources are the main factors in the water shortage problems in Iraq [1]. Restoring the marshes [20] [21] and the growing demand for water in Turkey and Syria will lead to dry the Tigris and Euphrates Rivers in 2040 [20]. Furthermore, the supply will be 43 and 17.61 BCM in 2015 and 2025 respectively while current demand is estimated between 66.8 to $77 \mathrm{BCM}$. These suggest that the Iraqi government need to take quick, prudent and firm action as a high priority. One of the solutions is the use of Water Harvesting techniques [1]. To overcome these problems in Iraq, there is a great need for prudent management of water resources and the adaptation of nonconventional techniques to augment water resources [1] [22].

In this research, the present conditions and future expectations are described to give ways and means to overcome the scarcity of water resources problems in Iraq.

\section{Climate}

The climate is mainly of continental, subtropical semi-arid type. The mountain region is of Mediterranean climate. In general, rainfall occurs from December to February or November to April in the mountain region. During winter the average daily temperature is about $16^{\circ} \mathrm{C}$ dropping at night to $2^{\circ} \mathrm{C}$ with possibility of frost. In summer however, it is very hot with an average temperature of over $45^{\circ} \mathrm{C}$ during July and August dropping to $25^{\circ} \mathrm{C}$ at night (Figure 2).

The annual rainfall in Iraq varies where it reaches $150 \mathrm{~mm}$ within the western desert, more than $1000 \mathrm{~mm}$ within the mountains at the north to about $200 \mathrm{~mm}$ at the eastern part of the country (Figure 3). The overall average annual rainfall is of the order of $213 \mathrm{~mm}$ per year. The rainy season begins in October and ends in April. It is evident from Figure 3 that annual rainfall increase from southwest towards northeast due to topographic effect. Furthermore, it can be noticed that individual topographic regions are characterized by their own climatic factors and rainfall values. It should be mentioned however, that despite the local climatic differences, all the regions have similar overall climatic features. This is due to the fact that Iraq as a whole is affected by its geographic position. When rainfall is used as a base to classify the climate, two seasons can be noticed:

a) Dry season starting in April to September.

b) Wet season starting in October to May.

It can be stated that October represent the transition period from dry to wet seasons while May representing the transition from humid to dry season.

The range of daily temperature varies greatly between day and night reflecting the continental climate. In addition, the trend in temperature increase is exactly the opposite to that of the rainfall's trend, where it increases from northeast toward southwest. The maximum daily temperature during dry season could rise to over $50^{\circ} \mathrm{C}$, while the minimum temperature during the wet season could reach $-14^{\circ} \mathrm{C}$ in Rutba and about $-8^{\circ} \mathrm{C}$ in Baghdad (Figure 2). It can also be noticed at the south, in Basrah in particular, that the temperature during summer is less than that of the surrounding areas due to high humidity resulting from being near to the Gulf.

Sunshine records indicate that during dry period, May-September, the average is more than $500 \mathrm{cal} / \mathrm{cm}^{2} /$ day while it is below this value during wet season (October-April). Meteorological record was used to calculate the
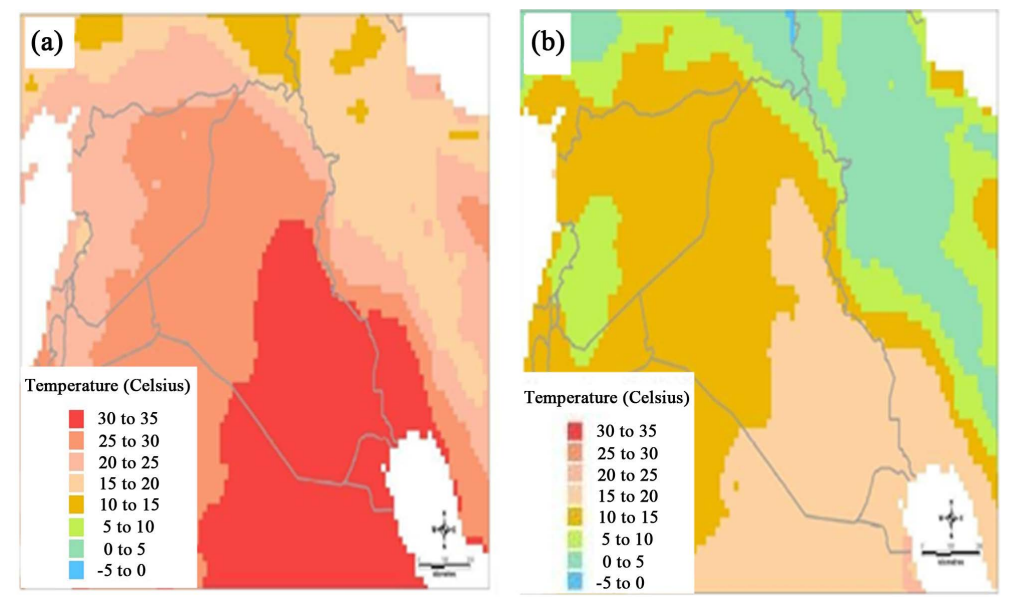

Figure 2. Mean maximum (a) and minimum (b) temperatures in Iraq. 


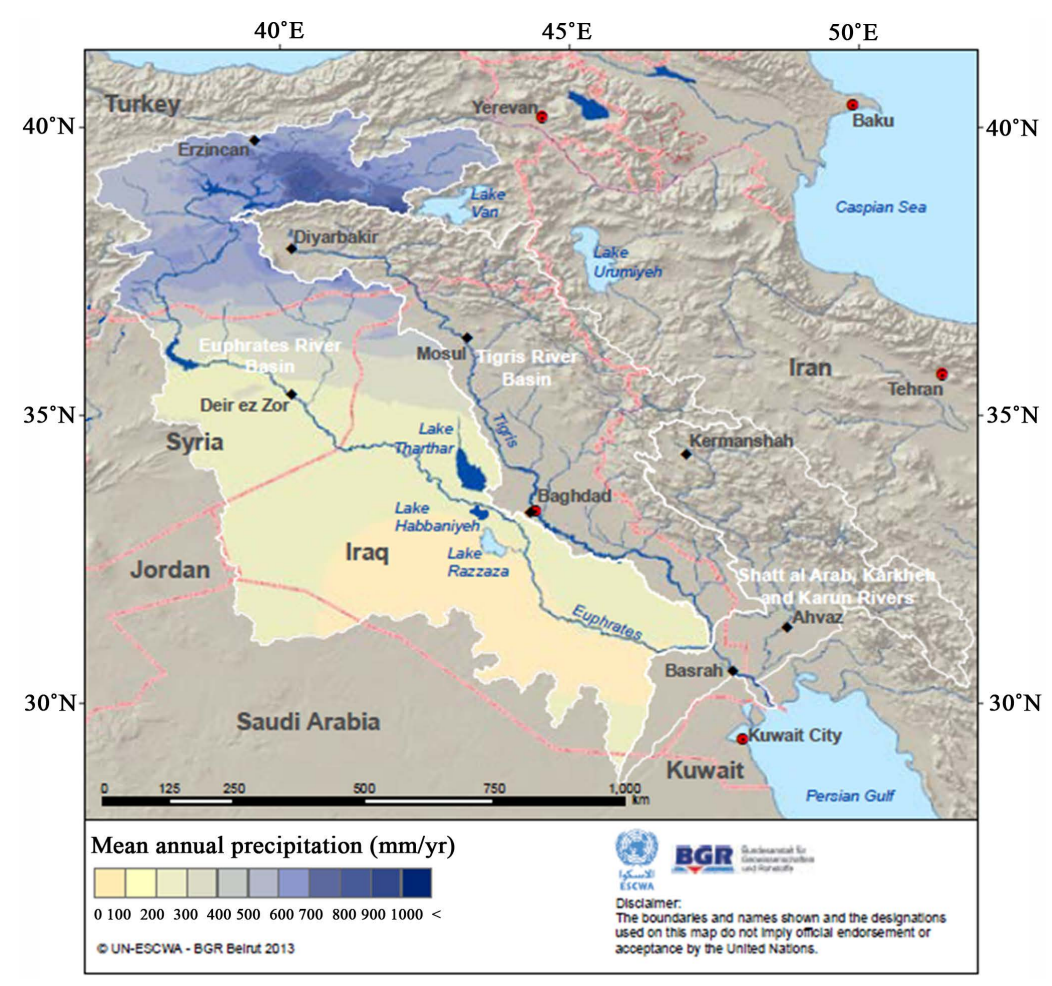

Figure 3. Rainfall map of Iraq [2].

evaporation and evapotranspiration values using penman method. The results show that the overall average evaporation and evapotranspiration is of the order of $1900 \mathrm{~mm}$ per year. Furthermore, the values show an increasing trend similar to that of the temperature increasing from northeast towards the southwest.

\section{Water Resources}

\subsection{Surface Water}

The rivers Tigris and Euphrates with their tributaries form the main surface resources in Iraq. Details of these basins can be found in Al-Ansari [1] (2013), Al-Ansari and Knutsson [22] and ESCWA [2]. The catchments area of these rivers is shared by five countries: Iraq, Turkey, Iran, Syria and Saudi Arabia, Table 1 and Figure 4.

Several ancient civilizations in the Mesopotamia were supported by basin irrigation from the Tigris and Euphrates Rivers since 5000 BC during Sumerian time. The ancient irrigation system was so efficient where it support wide spread cultivation of the land for many years without serious decline in land quality. Due to these marvelous water activities the term "hydraulic civilization" was used to describe this society.

Generally, the total annual flow of the Tigris and Euphrates Rivers is of the order $80 \times 10^{9} \mathrm{~m}^{3}$.This figure greatly fluctuates from year to year (Figure 5). Furthermore, floods and drought are themselves of variable magnitude. Such variations are due to changing metrological conditions. The period extending from October to February is referred to as variable flood period where discharges in both rivers fluctuate depending on intensity and duration of rainfall at their basins. This period is usually followed by what is known as steady flood period extending from March to April.

Flow records show that minimum and maximum annual flow of the Tigris was $19 \times 10^{9} \mathrm{~m}^{3}$ in 1930 and $10^{6} \times$ $10^{9} \mathrm{~m}^{3}$ in 1969, while for the Euphrates it was $9 \times 10^{9} \mathrm{~m}^{3}$ in 1974 and $63 \times 10^{9} \mathrm{~m}^{3}$ in 1969, respectively. Table 2 and Table 3 summarize the source and uses of water in both rivers.

\subsubsection{River Euphrates}

River Euphrates rises in the mountains of southern Turkey. It runs about $1178 \mathrm{~km}$ in Turkey before interring the Syrian territory where it runs $604 \mathrm{~km}$ to reach the Iraqi border. Inside Iraq the length of river is $1160 \mathrm{~km}$. the total length of the river from Turkey to its confluence with the River Tigris south of Iraq is $2940 \mathrm{~km}$, the total drainage 

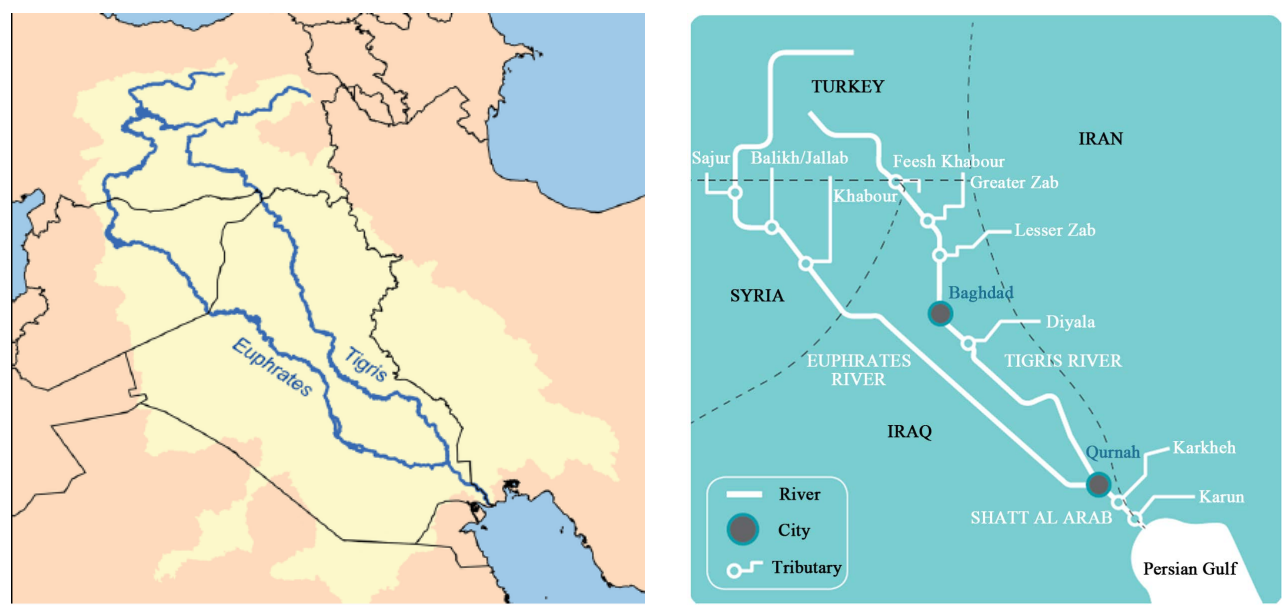

Figure 4. Catchments area of Rivers Tigris and Euphrates [2] [23].

Table 1. The area of Tigris and Euphrates Basins.

\begin{tabular}{ccccc}
\hline \multirow{2}{*}{ Countries } & \multicolumn{2}{c}{ Tigris River } & \multicolumn{2}{c}{ Euphrates River } \\
\cline { 2 - 5 } & Catchment Area $\left(\mathrm{km}^{2}\right)$ & Catchment Area (\%) & Catchment Area $\left(\mathrm{km}^{2}\right)$ & Catchment Area $(\%)$ \\
\hline Turkey & 57,614 & 12.2 & 125,000 & 28.2 \\
Syria & 834 & 0.2 & 76,000 & 17.1 \\
Iraq & 253,000 & 58 & 177,000 & 39.9 \\
Iran & 140,180 & 29.6 & - & - \\
Saudi Arabia & - & - & 66,000 & 14.9 \\
Total & 473,103 & 100 & 444,000 & 100 \\
\hline
\end{tabular}

Table 2. Sources and uses of the Euphrates River (million cubic meters (MCM) per year).

\begin{tabular}{|c|c|c|}
\hline Natural Flow & $\begin{array}{c}\text { Observed at Hit, Iraq } \\
\text { Removed in Turkey (pre-GAP) } \\
\text { Removed in Syria (pre-Tabqa) } \\
\text { Natural flow at Hit }\end{array}$ & $\begin{array}{c}29,800 \\
820 \\
2100 \\
32,720\end{array}$ \\
\hline $\begin{array}{l}\text { Pre-Kaban Dam } \\
\text { (before 1974) }\end{array}$ & $\begin{array}{c}\text { Flow in Turkey } \\
\text { Removed in Turkey } \\
\text { Entering Syria } \\
\text { Added in Syria } \\
\text { Removed in Syria } \\
\text { Entering Iraq } \\
\text { Added in Iraq } \\
\text { Iraqi Irrigation } \\
\text { Iraqi return flow (est.) } \\
\text { To Shatt al-Arab }\end{array}$ & $\begin{array}{c}30,670 \\
(820) \\
29,850 \\
2050 \\
(2100) \\
29,800 \\
0 \\
(17,000) \\
4000 \\
16,800\end{array}$ \\
\hline $\begin{array}{l}\text { Full Use Scenario } \\
\quad \text { (circa 2040) }\end{array}$ & $\begin{array}{c}\text { Flow in Turkey } \\
\text { Removed in Turkey } \\
\text { Entering Syria } \\
\text { Removed in Syria } \\
\text { Return flow and Tributaries (Turkey, Syria) } \\
\text { Entering Iraq } \\
\text { Removed Iraq } \\
\text { Return flow in Iraq } \\
\text { Deficit to Shatt Al-Arab }\end{array}$ & $\begin{array}{c}30,670 \\
(21,600) \\
9070 \\
(11,995) \\
9484 \\
6559 \\
(17,000) \\
4000 \\
(6441)\end{array}$ \\
\hline
\end{tabular}


a) pre 1973

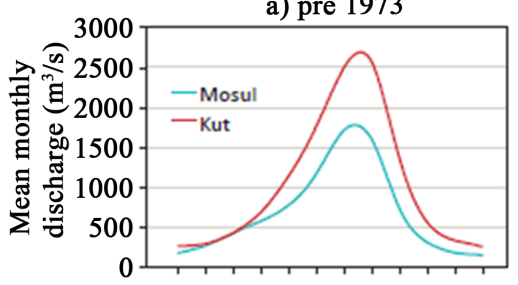

Tigris

a) $1938-1973$
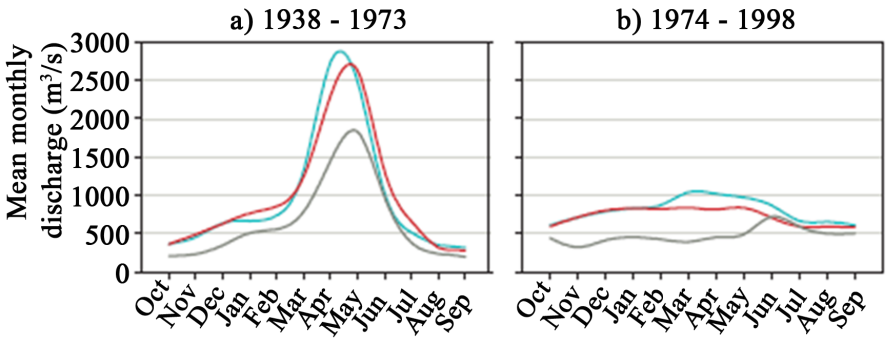

Euphrates

Figure 5. Mean monthly flows of the Tigris and Euphrates Rivers at different gauging stations for different time periods [2].

b) post 1973

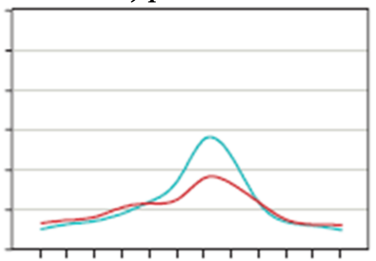

b) $1974-1998$

\section{(1)}

iti

(1)

Table 3. Sources and uses of the Tigris River (MCM per year).

\begin{tabular}{|c|c|c|c|}
\hline & Pre-GAP Project & Post GAP 2000 AD & Natural Flow \\
\hline Flow From Turkey & 18,500 & 18,500 & 18,500 \\
\hline Removed in Turkey & 0 & 6700 & \\
\hline Entering Iraq & 18,500 & 11,800 & \\
\hline Inflows to Mosul & 2000 & 2000 & 2000 \\
\hline Greater Zab & 12,100 & 13,100 & 13,100 \\
\hline Lesser Zab & 7200 & 7200 & 7200 \\
\hline Other & 2200 & 2200 & 2200 \\
\hline Sub-Total & 43,000 & 36,300 & 43,000 \\
\hline Reservoir evaporation & 0 & $(4000)$ & \\
\hline Irrigation (to Fatha) & $(4200)$ & $(4200)$ & \\
\hline Return Flow & 1100 & 1100 & \\
\hline Adhaim & 800 & 800 & 800 \\
\hline Irrigation(to Baghdad) & $(14,000)$ & $(14,000)$ & \\
\hline RETURN Flow & 3600 & 3600 & \\
\hline Domestic Use & $(1200)$ & (1900) & \\
\hline Diyala River & 5400 & 5400 & 5400 \\
\hline Irrigation & (5100) & (5100) & \\
\hline Return Flow & 1300 & 1600 & \\
\hline Sub-Total & 30,700 & 19,600 & 49,200 \\
\hline $\begin{array}{l}\text { Reservoir evaporation } \\
\text { Irrigation to Kut } \\
\text { Return Flow }\end{array}$ & $\begin{array}{c}0 \\
(8600) \\
2200\end{array}$ & $\begin{array}{c}900 \\
(8600) \\
2200 \\
\text { (to outfall drain) }\end{array}$ & \\
\hline Total Shatt Al-Arab & 24,300 & 14,100 & 49,200 \\
\hline
\end{tabular}

area of the river catchments is $444,000 \mathrm{~km}^{2}$, Table 3, of which $28 \%, 17 \%, 40 \%$ and $15 \%$ lie in Turkey, Syria, Iraq and Saudi Arabia, respectively.

The Euphrates River rises east the Anatolian plateau between Wan lake and Black Sea in Turkey with two main tributaries (Figure 4):

a) Furat Su: This forms the northern tributary where it rises from the mountains situated northeast Ardhroom area with altitudes varying from 1800 to $3937 \mathrm{~m}$ above sea level. The total length of the tributary reaches $510 \mathrm{~km}$. 
b) Murad Su: This forms the southern tributary where it rises north of Wan Lake at areas having altitude of 2350 to $3519 \mathrm{~m}$ above sea level with a total length of $600 \mathrm{~km}$.

Both tributaries join together $5 \mathrm{~km}$ north of Keban city. At Keban area the Keban dam was constructed with a total reservoir capacity of $30.5 \times 10^{9} \mathrm{~m}^{3}$. The average annual flow of the Euphrates River in this area is $672 \mathrm{~m}^{3} / \mathrm{s}$. The united river length in Turkey is $455 \mathrm{~km}$. The shape of the catchments of the river in Turkey is a fan shaped which collects runoff at rainy periods in a short period of time causing sudden flood peak. The Euphrates River inters the Syrian border near Jorablus and flow to Albokamal at the Syrian-Iraqi border. The catchment's area of the river before entering Iraq reaches $201,000 \mathrm{~km}^{2}$.

In Syria, three tributaries join the Euphrates:

a) Sabor River: total length of the river is $108 \mathrm{~km}$, joining the Euphrates, from the right, $30 \mathrm{~km}$ south of Tripoli city. The average discharge of the river is $3 \mathrm{~m}^{3} / \mathrm{s}$.

b) Belaikh River: The length of this river is $105 \mathrm{~km}$ and joins the Euphrates from the left south of Raka city downstream Tabaka dam. The average discharge of the river is $36 \mathrm{~m}^{3} / \mathrm{s}$ and its catchment area is $14,400 \mathrm{~km}^{2}$.

c) Khabor River: The length of this river is $446 \mathrm{~km}$. Its catchment area is 36,900 $\mathrm{km}^{2}$ and lies in Turkey and Syria. Four small streams, i.e. Jaja, Jabjab, Etehad Aracha Alsaghir and Etehad Aradha Alkabeer, join this river. The khabor join the Euphrates south of Dier Al-Zor city and its mean daily discharge is $55.8 \mathrm{~m}^{3} / \mathrm{s}$ and could reach $500 \mathrm{~m}^{3} / \mathrm{s}$ during flood.

There are several dams constructed on the Euphrates River in Syria. One of the main dams is called "Tabaka". The storage capacity of this dam is $11.6 \times 10^{9} \mathrm{~m}^{3}$ (life storage $7.4 \times 10^{9} \mathrm{~m}^{3}$ ). The maximum, minimum and mean discharge of the river Euphrates at Tabaka dam is 8500, 450 and $1300 \mathrm{~m}^{3} / \mathrm{s}$, respectively. There are three more large dams; Tersanah, Teshreen and Muhardah with storage capacities of $225 \times 10^{6} \mathrm{~m}^{3}, 210 \times 10^{6} \mathrm{~m}^{3}$ and $50 \times$ $10^{6} \mathrm{~m}^{3}$, respectively. In addition, 84 other small and medium size dams exist. The largest among these dams is known as Babalhadied with a storage capacity of $25 \times 10^{6} \mathrm{~m}^{3}$, while the storage capacity of the smallest dam is $30,000 \mathrm{~m}^{3}$.

The length of the river Euphrates in Iraq from the Syrian-Iraqi border at Hussaybah to its confluence with the Tigris River is $1160 \mathrm{~km}$. once the river enters Iraq it trends toward the east and southeast to reach Anah city 100 $\mathrm{km}$ south of Hussaybah. The river then runs $220 \mathrm{~km}$ to reach Hit, with a river channel slope of 1:320 m. The channel is characterized by its shallow depth, large width and meanders. Islands are also noticed at the river channel. No tributaries join the Euphrates River inside Iraq apart from dry valleys originating from western desert. These valleys supply the river with flood water at rainy season from the desert. The minimum and maximum recorded discharges at Hit are 55 on 5/9/1973 and $7460 \mathrm{~m}^{3} / \mathrm{s}$ on 13/5/1969.

The river runs $63 \mathrm{~km}$ south Hit to reach Ramadi city with a width reaching $250 \mathrm{~m}$. At this area, Ramadi barrage was constructed to supply Warrar stream with water. This stream supplies Habariya Lake with excess water from the Euphrates during flood period. The length of this stream is $8.5 \mathrm{~km}$ which is designed to discharge up to 2800 $\mathrm{m}^{3} / \mathrm{s}$. Water stored in Habaniya Lake can brought back to the river Euphrates when required through Dhiban stream which is located $42 \mathrm{~km}$ south of Ramadi city. In case of continuous flood flow, Habaniya lake cannot accommodate huge volumes of water and thus it was connected to Razazah lake and then to Abudibis marsh to release excess water.

South of Ramadi city the river flows $72 \mathrm{~km}$ to reach Falujah city. A complex of canals system was constructed at this section of the river. A canal was dug from Tharthar large lake to supply the Euphrates River during drought periods; the canal joins the river $35 \mathrm{~km}$ north of Falujah city. The canal is designed to discharge water up to 1100 $\mathrm{m}^{3} / \mathrm{s}$. It has a diversion which can supply excess water to the Tigris River if required. This diversion canal is $65 \mathrm{~km}$ long.

The Euphrates River runs south about $110 \mathrm{~km}$ to reach Hindiyah barrage. The river runs through fluvial deposits in this area. It should be mentioned however, that the Euphrates River channel inside Iraq upstream Hindiyah is higher by $7 \mathrm{~m}$ than Tigris river channel. This is due to the fact that the Euphrates runs on the edge of the western plateau. This phenomenon was used since ancient times to dug irrigation canals from the Euphrates River running toward the Tigris River.

At Hidiyah, the river is known as Hindiyah River where it flows south to reach Kifil city $18 \mathrm{~km}$ south of Hindiyah barrage. South of Kifil, the river splits to eastern channel (Shamiyah) which takes $40 \%$ of the flow and western channel (Kufa) taking the remaindering $60 \%$ of the flow. On shamiyah river there are various regulating schemes established for a number of irrigation projects, i.e. Danaieb Alshanafiyah, Shalal Danaieb Alshanafiyah, Khuman and Naghshiyah regulating schemes. This channel joins the Euphrates River again 8 km upstream Sha- 
nafiyah city. The distance from Kifil to Shanafiyah is $99 \mathrm{~km}$.

As far as the other channel, the Kufa, it runs to Abusskhair city and splits into two main channels. The small channel (on the right of the main channel) supplies four small irrigation streams, the main channel south of Abusskhair as Mushkhab River where Mushkhab barrage was established. The water flows to the south to reach Qadisiyah city and it again splits and joins again to form one channel. This channel joins Shamiyah channel again at Shanafiya city.

The river continues to run south for $105 \mathrm{~km}$ where it reaches Simawah city. After that the river Euphrates reaches Nasiriyah city. It should be mentioned however that this section of the river (Simawah-Nasiriyah section) has a number of irrigation projects and small intake stream. South of Nasiriyah city the river runs toward Alshiyokh city and then enters Hammar Lake. Two channels leave Hammar Lake. The first joins the Tigris River at Qurna City while the other, the southern one, joins Shatt Al-Arab River at Karmat Ali.

\subsubsection{River Tigris}

The total drainage area of the Tigris River is $235,000 \mathrm{~km}^{2}$ distributed between Turkey (17\%), Syria (2\%), Iran (29\%) and Iraq (52\%) (Figure 4). The overall length of the river is $1718 \mathrm{~km}$. It rises at the southeastern slope of Taurus Mountains at two sites, the western site is located near Diar city, $1500 \mathrm{~m}$ above sea level, with a discharge of $64 \mathrm{~m}^{3} / \mathrm{s}$ while the eastern site, known as Butman Su, near Sinan city a $2700 \mathrm{~m}$ above sea level with a discharge of $96.3 \mathrm{~m}^{3} / \mathrm{s}$. The river runs in a narrow valley bounded by Mardin Mountain range from the right and Raman Surat Hills from the left. Further down, another tributary (Karzan) joins the river near Bishwi village. The river runs south through rough mountainous area till it is joined by another tributary (Hazu) near ZEU village $240 \mathrm{~km}$ north of the Iraqi border. The discharge of this tributary is $59 \mathrm{~m}^{3} / \mathrm{s}$. The river then runs in a plain area and joined by Butan Su River, with a discharge of $20.3 \mathrm{~m}^{3} / \mathrm{s}$, to form the united Tigris River.

The river enters Iraq $4 \mathrm{~km}$ north Fieshkhabur near Zakha city. The Tigris is joined by its first tributary inside Iraq which is known as Khabur River. This tributary is $100 \mathrm{~km}$ long, it catchment area is $6268 \mathrm{~km}^{2}$ with an average, maximum and minimum discharge of $68 \mathrm{~m}^{3} / \mathrm{s}, 1270 \mathrm{~m}^{3} / \mathrm{s}(11 / 4 / 1963)$ and $8 \mathrm{~m}^{3} / \mathrm{s}$ (6 - 14/9/1962), respectively. The Tigris River runs south for about $188 \mathrm{~km}$ in a hilly area to reach Mosul city. At Mosul the average, maximum and minimum discharge of the river is $668 \mathrm{~m}^{3} / \mathrm{s}, 7740 \mathrm{~m}^{3} / \mathrm{s}$ (2/5/1972) and $85 \mathrm{~m}^{3} / \mathrm{s}$ (October, 1935) respectively. The elevation of the channel bed is $225 \mathrm{~m}$ above sea level.

About $49 \mathrm{~km}$ south of Mosul toward Sharkat city, the Tigris joins its biggest tributary, the Greater Zab. The catchment of this tributary lies in Turkey, Iran and Iraq. Its total length is $437 \mathrm{~km}$ with a mean, maximum and minimum discharges of $450 \mathrm{~m}^{3} / \mathrm{s}, 9710 \mathrm{~m}^{3} / \mathrm{s}(2 / 4 / 1969)$ and $60 \mathrm{~m}^{3} / \mathrm{s}$ (22/11 and 4/12/1958) respectively. It supplies $28.7 \%$ of the Tigris water.

The Tigris River runs south toward Fatha gorge. About $30 \mathrm{~km}$ north of Fatha, the Lesser Zab tributary joins the river Tigris. The total catchment area of this tributary is $22,250 \mathrm{~km}^{2}$ of which $5975 \mathrm{~km}^{2}$ lie in Iran and the remainder in Iraq. The total length of the river is $456 \mathrm{~km}$. The mean, maximum and minimum discharges of Lesser Zab are $227 \mathrm{~m}^{3} / \mathrm{s}, 3420 \mathrm{~m}^{3} / \mathrm{s}$ on 8/3/1954 and $6 \mathrm{~m}^{3} / \mathrm{s}$ on 14/5/1964, respectively. The river Tigris mean, maximum and minimum discharges at Fatha gorge are $1349 \mathrm{~m}^{3} / \mathrm{s}, 16,380 \mathrm{~m}^{3} / \mathrm{s}$ on 3/4/1969 and $200 \mathrm{~m}^{3} / \mathrm{s}$ in October 1930, respectively.

Further south, the Tigris River enters the Mesopotamia plain $20 \mathrm{~km}$ north of Samara city and then Balad city. The Adhaim tributary joins the Tigris $15 \mathrm{~km}$ south Balad. The tributary drains an area of 13,000 $\mathrm{km}^{2}$ lying within Iraq. Its length is $330 \mathrm{~km}$. The mean daily discharge is of the order of $25.5 \mathrm{~m}^{3} / \mathrm{s}$; while the maximum recorded on 19/10/1960 reached $3520 \mathrm{~m}^{3} / \mathrm{s}$. this tributary runs almost dry during June to November each year. The banks of the river Tigris south its confluence with Adhaim tributary are below the maximum flood peak level by $3 \mathrm{~m}$ from the left and $1.8 \mathrm{~m}$ from the right.

Further to the south, the river reaches Baghdad. At Baghdad the mean, maximum and minimum discharges are $1140 \mathrm{~m}^{3} / \mathrm{s}, 7640 \mathrm{~m}^{3} / \mathrm{s}$ on 12/2/1941 and $163 \mathrm{~m}^{3} / \mathrm{s}$ in October, 1955 respectively. The slope of the channel is very low i.e. $6.9 \mathrm{~cm} / \mathrm{km}$. About $31 \mathrm{~km}$ south of Baghdad, the last main tributary "Diyala” joins the Tigris. Diyala's drainage basin is $31,896 \mathrm{~km}^{2}$ of which $20 \%$ lies in Iran and the rest in Iraq. The mean daily discharge is $182 \mathrm{~m}^{3} / \mathrm{s}$ while the maximum and minimum discharges are $3340 \mathrm{~m}^{3} / \mathrm{s}$ on 25/3/1954 and $12 \mathrm{~m}^{3} / \mathrm{s}$ on 7/9/1960, respectively.

Downstream the confluence of the Tigris-Diyala River, the Tigris channel is characterized by its large number of meanders. In addition, the river discharge steadily decreases downstream due to losses. These losses include evaporation, infiltration and mainly water withdrawal through irrigation canals. Important irrigation canals includes: Gharaf, south Kut city, Great Majar, South Emarah city, Mushrah and Kahlaa, South Emarah city, and 
Majariah canal, South Qalaat Salih. In addition, this stretch of the river is well known by the abundant occurrence of big marshes on both sides of the Tigris River. There are many small streams running from Iran toward Iraq where they discharge their water in the marshes e.g. Karkha stream discharging its water in Hiwazah marsh.

The Tigris channel reaches its minimum width at Kasarah area south of Emarah city. At Qalaat Salih the mean daily discharge of the river is $80 \mathrm{~m}^{3} / \mathrm{s}$. Downstream this city the river joins the Euphrates River at Qurnah city forming Shatt Al-Arab River.

\subsubsection{Shatt Al-Arab River}

Shatt Al-Arab River is formed after the confluence of Tigris and Euphrates Rivers at Qurnah in Iraq (Figure 6). Its total length is $192 \mathrm{~km}$ and its drainage area is $80,800 \mathrm{~km}^{2}$. Its width is about $300 \mathrm{~m}$ near Qurnah and increases downstream to $700 \mathrm{~m}$ near Basra city and to about $850 \mathrm{~m}$ near its mouth at the gulf area. Karun and Karkha Rivers usually contributes 24.5 and 5.8 billion cubic meters (BCM) annually respectively (Figure 6). This forms about $41 \%$ of the water of Shatt Al-Arab. Its annual discharge at Fao city reaches $35.2 \times 10^{9} \mathrm{~m}^{3}$. Shatt Al-Arab River is characterized by its high sediments which resulted in the formation of large number of islands during its course.

\subsection{Groundwater}

Kahariez mountain channels and hand dug wells were common practices in the ancient history of Iraq. Some of these wells and Kahariez are still in use now. Large numbers of villages were previously built near springs and later wells were dug to provide water for the inhabitants. The geographic distribution of springs and wells marked the travel routes in ancient Iraq. Development and utilization of groundwater started in 1935 where the first groundwater well was mechanically drilled. This development went through four main stages:

I. Stage one: this stage started in the mid-1930s to the beginning of the 1950s. During this stage wells were drilled without any scientific investigation or studies. Drilling operations were executed to provide water for villages and remote areas. Few basic reports on groundwater resources were written during this stage.

II. Stage two: this stage started during the 1950s toward the end of the 1960s. This stage is marked by the activities of foreign consultants and contractors. Companies like Parsons and INGRA carried out countrywide surveys for groundwater resources in Iraq. A numbers of wells were drilled to for the purpose of the study required. This operation resulted in a huge survey report on the groundwater resources of Iraq published in 13 volumes.

III. Stage three: this stage started at the end of the 1960s. The most important feature of this stage was the availability of Iraqi geologists and drilling engineers to drill the required wells all over Iraq. This stage was relatively poor in its scientific research and studies where field drilling operations were predominant and hundreds of wells were established.

IV.Stage four: this stage started during the 1970s and marks scientific research for groundwater investigations and utilization. This was executed by national and foreign organizations and companies. The Ministry of Irrigation (now Ministry of Water Resources) was the official body responsible for these operations and practices. During this period the state company for water wells drilling was established.

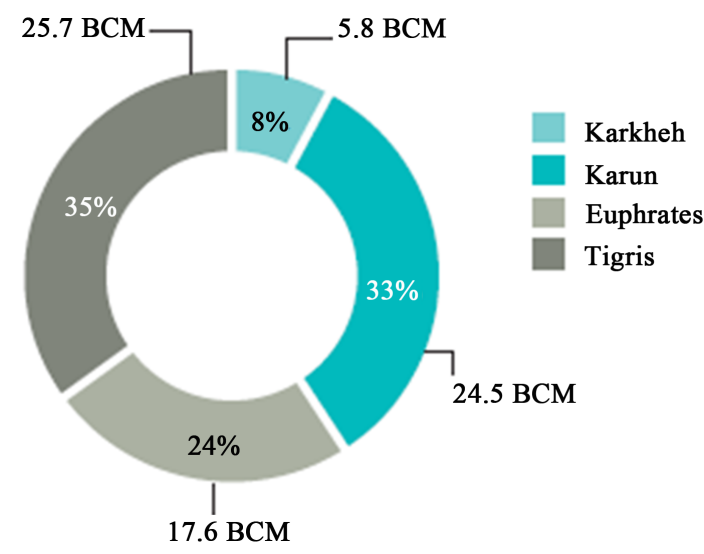

Figure 6. Water contribution to Shatt Al-Arab River [2]. 
Despite the large number of groundwater wells that exists now, ground water utilization in Iraq forms a minor percentage (5\% - 7\%) of the water resources of the country despite its extensive use [24]-[32]. Ground water resources in Iraq are described in details by Al-Ansari [24], Al-Sayab et al. [25], Al-Ansari et al. [26]-[30], Alsam et al. [31] and Kransy et al. [32]. However, using the geological, structural and physiographic characteristics, groundwater in Iraq can be summarized by divided to five main zones:

\subsubsection{Mountain Region}

This region is confined to a small area, 20,000 $\mathrm{km}^{2}$, in the north and northeastern part of Iraq. It is characterized by the availability of groundwater resources. This region can be divided into three sub regions on the basis of petrology of the aquifers, their age and distribution.

1) Sub region one: this sub region covers limestone, dolomites and other hard rocks. The age of the rocks is cretaceous or older. The rocks of this area are characterized by their joints and fissures where groundwater is usually found within these features. The quality of groundwater is good and can be used for different purposes. The reserve is considered medium. The groundwater in this region is usually utilized by springs.

2) Sub region two: This sub region is characterized by its weak sedimentary rocks e.g. sandstones, shale and marl, etc. The age of the rocks is cretaceous where fine grained sandstones are the principle aquifers in the area as well as marls and siltstones, where the rocks are usually jointed. The aquifers are usually of the confined type and distributed within the valleys at different depths, there is no detailed exact study regarding the quality of groundwater but it had been estimated to be medium and of good quality. Water is usually utilized through springs, hand and mechanical dug wells.

3) Sub region three: The rocks in this sub region are composed of Pleistocene and Quaternary recent valley deposits. Gravel, conglomerates, sand and sandstones form the main aquifers. Groundwater is found at shallow depths (about $30 \mathrm{~m}$ ) with very good quality (salinity 170 - $350 \mathrm{ppm}$ ) and with adequate quantities. Hand dug wells, mechanical wells, springs and kahariez are the methods of groundwater utilization in this area. Kalatdiza, Rania and Shahrzor are the main important groundwater basins within this sub region.

\subsubsection{Plateau and Hill Region}

This region border's the mountain region and covers an area of $62,000 \mathrm{~km}^{2}$. The main aquifers are of Pliocene and Pleistocene age (sometimes Miocene). The aquifers of this region are considered to be of the highest quality and have the best quantity. The hills are usually folded strata and are parallel extending from NW-SE. the elevation of these hills is about $200 \mathrm{~m}$ in the south while it increase's to $500 \mathrm{~m}$ in the north. These hills are usually narrow with very wide plains between adjacent regions. This region can be sub divided in to two sub regions, according to the rock type of the aquifers their age and distribution:

A. Sub region one: The main aquifers are Bakhteiari Formation (Pliocene-Pleistocene) and recent alluvial deposits. The aquifers are composed of conglomerates, sandstones, sand and gravel. The thickness of the aquifer varies from place to place and sometimes reaches $400 \mathrm{~m}$. Groundwater depth does not exceed $50 \mathrm{~m}$ below ground level and saturated thickness reaches $400 \mathrm{~m}$. The salinity of groundwater varies from $300 \mathrm{ppm}$ (Irbil basin) to $2500 \mathrm{ppm}$ (Mandeli and Wend). The main basins are:

- Irbil plain: This plain extends between the L-Zab River at south and the G.Zab River at north with a total area of $2000 \mathrm{~km}^{2}$. The aquifers are composed of conglomerates, sandstone, sand and gravel. The salinity range is $300-500 \mathrm{ppm}$. The yield of the wells is 10 - $30 \mathrm{l} / \mathrm{s}$ while the groundwater level is 25 - $40 \mathrm{~m}$ above sea level.

- Altonkupri plain: This plain is $20 \mathrm{~km}$ north of KirkEU, bordered by the Klilkhal Mountain at the northeast, the L-Zab River from the north-northwest and the Khasa Su River from the south east, the quality of water is good and the yield of the wells varies from 7 to $30 \mathrm{l} / \mathrm{s}$.

- Aqra plain: This plain is bordered by the Aqra Mountain from north, the Khabour River from the west, the G. Zab River from east and the Maklob Mountain from the south. The quality of water is very good (salinity range $300-500 \mathrm{ppm}$ ) and the yield of the wells varies from 10 - $30 \mathrm{l} / \mathrm{s}$.

- Wen River basin: This basin extends from Khanaqien city at the northeast toward the confluence of the Wend River with the Diyala River at the southwest. The quality of groundwater is good to medium (salinity 500 $2000 \mathrm{ppm}$ ) while the yield of wells is 5 - $20 \mathrm{l} / \mathrm{s}$.

B. Sub region two: Groundwater in this area is found in Fars Formation beds. The quality and quantity of groundwater is considered medium to poor. The aquifers are mainly sandstones and shales. The most important basins are: 
- North Sinjar plain: these basin extents from Sinjar Mountain at the south towards the Iraqi-Syrian border at the north covering an area of $1360 \mathrm{~km}^{2}$. The salinity of water is $300-2500 \mathrm{ppm}$ but it ranges $3000-13,000 \mathrm{ppm}$ in the southern parts of the basin. The yield of the wells is of the order of $7 \mathrm{l} / \mathrm{s}$.

- Rabia plain: Groundwater aquifers are restricted to sandstone bed of the Upper Fars Formation. The salinity range is $500-1000 \mathrm{ppm}$, while it ranges 1000 - $5000 \mathrm{ppm}$ in the southern and eastern parts of the basin. Wells yield range $7-12$ l/s.

- Tikrit-Sammara basin: This area is bordered by Hemrin and Makhul mountain ranges from the northeast, the Tharthar depression from the west and the Adhaim River from the east. The salinity range $2000-5000$ ppm whiles the yield of the wells range $7-10 \mathrm{l} / \mathrm{s}$.

\subsubsection{Mesopotamian Plain (Delta) Region}

This region covers the area bounded by the Rivers Tigris and Euphrates south of Baghdad to the Arabian Gulf. The groundwater in this region is usually found within the recent alluvial deposits. The Tigris and Euphrates are the main source for groundwater in this region. The salinity varies with depth where it is of the order of $3500 \mathrm{ppm}$ at depths less than $20 \mathrm{~m}$ while it reaches 20,000 ppm at greater depths, the groundwater table is very shallow near the ground level. In restricted areas fresh water of very good quality can be found overlying saline groundwater.

\subsubsection{Jezira Plain Region}

This region occupies the northwestern part of Iraq, bordered by Sinjar mountain from the north, the Tharthar depression from the east, the Euphrates river from the south and the Iraqi-Syrian border from the west the area is characterized by its almost horizontal beds, where the Upper and Lower Fars Formations are usually exposed on the surface. These formations usually act as aquifers. The water quality of this region is usually poor due to high salt content from Lower Fars beds. Groundwater quality can be considered medium (salinity 3000 - 5000 ppm) within the Upper Fars beds west of the Sinjar area but salinity increases toward the south.

\subsubsection{Western Desert region}

This region covers an area of about 226,000 $\mathrm{km}^{2}$. It is bordered from the northwest by the Iraqi-Syrian border, from the west by the Iraqi-Jordanian border, from the southwest by Saudi Arabia, from the southeast by Kuwait and the Euphrates River from its northern border. This region forms a plain area with no marked physiographic features. The slope of the area is directed from the Iraqi-Saudi Arabia border in the south west towards the Euphrates River in the north east; and from the Iraqi-Syriaian border in the west toward the Euphrates River in the east. The maximum altitude reaches $900 \mathrm{~m}$ above sea level near the Iraq-Syria border while the minimum is less than $50 \mathrm{~m}$ above sea level near the Hamar marsh.

The area is characterized by its large number of seasonal streams and lakes. The Khir valley divides the region into what is known as the north Badia and the south Badia. Groundwater forms the main source of water in this area and it can be found in different geologic formations. Generally groundwater movement is toward the northeastern part of the desert where in some places it runs to the surface in the form of springs.

Using the type of aquifers and its age the area can be divided into three main sub regions:

\section{Sub region one (Dibdibah):}

This area is confined to the extreme south eastern part of the region. The main aquifer is the Dibdibah Formation (Pliocene-Miocene) which is mainly composed of sand, gravel and gypsum. The thickness of this formation varies from place to place and it can reach $140 \mathrm{~m}$.

Groundwater salinity is relatively high $(2500-8000 \mathrm{ppm})$. Generally shallow groundwater (top $10 \mathrm{~m}$ of the saturated thickness) is of a better quality relative to deeper water. Yield of the wells ranges from 5 to $10 \mathrm{l} / \mathrm{s}$. Utilization of groundwater is extensive in this area for agricultural purposes especially near the Zubair-Safwan area. Despite the high salinity of the water, agricultural activities are very successful which might be due to the light and higher porosity of the soil.

\section{Sub region two (Calcareous rock area):}

This area covers most of the western desert region and is characterized by its calcareous rock of different geologic ages (Miocene to Tertiary). The most important formations are: Dammam, Umerdhumah, Tagarat, Masad and Euphrates.

The rocks of the area are jointed and fractured with thicknesses reaching $400 \mathrm{~m}$. Groundwater occurs at a depth of $300 \mathrm{~m}$ and the aquifers are usually unconfined except the eastern parts where they are of a confined type. The salinity range is $2000-5000 \mathrm{ppm}$. The yield of the wells is usually $4-25 \mathrm{l} / \mathrm{s}$. the most promising basins for 
groundwater utilization are:

- Salman basin: this basin covers $35,000 \mathrm{~km}^{2}$ in the southern desert. Three main aquifers are found in this basin (Dammam, Umerdhumah and Tayarat). Groundwater depth is usually 50 - $130 \mathrm{~m}$ while the salinity is 2000 $8000 \mathrm{ppm}$. The yield of the wells is $3-10 \mathrm{l} / \mathrm{s}$.

- Hawar-Muainah basin: This basin is located within the southern desert. The aquifers are composed of limestone and dolomite. Groundwater depth is 75 - $110 \mathrm{~m}$ with salinity range 2800 - $3500 \mathrm{ppm}$. The average yield of well reaches $15 \mathrm{l} / \mathrm{s}$.

- Arar Valley basin: The area of this basin is $2800 \mathrm{~km}^{2}$. Umerdhumah and Tayarat Limestone beds form the main aquifers of this basin. The salinity is $700-3000 \mathrm{ppm}$ and the yield of wells is $25-30 \mathrm{l} / \mathrm{s}$.

- WadiKhir basin: The area of this basin is $3000 \mathrm{~km}^{2}$. The main aquifers are Dammam and Umerdhumah Limestone beds. The salinity is 1700 - $3000 \mathrm{ppm}$ and wells yield is $30 \mathrm{l} / \mathrm{s}$.

- WadiHamer basin: This basin covers $3400 \mathrm{~km}^{2}$ in the northern desert. The main aquifer is Tayarat Limestone Formation. The salinity is $500-3000 \mathrm{ppm}$ and well yield varies from 20 to $25 \mathrm{l} / \mathrm{s}$.

- Kasra area basin: This basin is located in the northern desert about $125 \mathrm{~km}$ west of Ramadi city. It extends between the Ghadof valley at the north and the Abyiadh valley at the south. The basin is $75 \mathrm{~km}$ in length and 50 $\mathrm{km}$ in width. Tayarat Limestone Formation is the main aquifer. The quality of water is excellent to very good, salinity 160 - $1000 \mathrm{ppm}$ and the average yield of wells is $25 \mathrm{l} / \mathrm{s}$.

\section{Sub region three (Sandstone area):}

This sub region is characterized by cretaceous and older rocks and covers a wide area within the northern desert. Groundwater is found in sandstone and limestone beds at depths of $50-300 \mathrm{~m}$. The yield of wells varies from less than 1 l/s to 20 l/s in confined and unconfined aquifers. The main aquifers are: Mehawir, Ubaid, Mulusa, Qaara and Sufi.

Qaara Formation (Upper Permian - middle and lower Triassic) is the most important aquifer with a varying thickness from 180 to $720 \mathrm{~m}$. This formation contains two aquifers. The first is $150-450 \mathrm{~m}$ deep. The yield of this aquifer is $2-10 \mathrm{l} / \mathrm{s}$ with salinity ranging $550-3000 \mathrm{ppm}$. The second aquifer is $700 \mathrm{~m}$ deep with high groundwater yield, up to $20 \mathrm{l} / \mathrm{s}$. The salinity is of the order of $3000 \mathrm{ppm}$. It should be mentioned however that the most promising areas for water utilization is the Qaara depression and Turaibiel.

Despite the presence of the great Tigris and Euphrates Rivers, groundwater is considered the only source of water in the western desert and $70 \%$ of water consumed by villages in north Iraq. Thousands of wells, Table 4 ,

Table 4. Number of groundwater wells drilled in each governorate in Iraq.

\begin{tabular}{cc}
\hline Governorate & Number of Wells \\
\hline Duhok & 410 \\
Naunawa & 1299 \\
Erbil & 1286 \\
Sulaymaniah & 423 \\
Tameem & 1093 \\
Diyala & 647 \\
Salahaldin & 1118 \\
Baghdad & 308 \\
Anbar & 608 \\
Muthana & 201 \\
Qadisiya & 6 \\
Karbala & 148 \\
Najaf & 286 \\
Wasit & 116 \\
Mesan & 80 \\
Dhiqar & 17 \\
Basra & 576 \\
Babil & 30 \\
Total & $\mathbf{8 7 5 2}$ \\
\hline & \\
\hline
\end{tabular}


were drilled in different parts of Iraq for various purposes, especially in the 1980s where a large number of wells were drilled for agricultural purposes.

The total number of wells drilled up to 1990 reached 8752 of which 1200 are used for agricultural purposes. These wells were drilled by the government. The number of wells drilled by the private sector reached 400 . After the Iraq-Kuwait war no records are available about the number of wells drilled. It is believed that a large number of wells drilled during the 1990s where the government encouraged the private sector to increase agricultural productivity due to UN sanctions.

It is believed that groundwater utilization will be tremendously important in Iraq in the near future due to:

About $90 \%$ of the irrigation practice in Iraq depends largely on Tigris and Euphrates Rivers. These activities are confined to areas within the vicinity of these rivers and the Mesopotamian plain. This leaves about $60 \%$ of the total area of Iraq where surface water is not available. This fact will inevitably increase the importance of groundwater utilization to secure food for the continuous increasing population in the country.

The increasing water projects in Turkey, e.g. GAP, and Syria's intention of reducing the flow of the Tigris and Euphrates to Iraq in the near future. One of the solutions to overcome this crisis is to increase groundwater utilization.

There are increasing problems with regard to the allocation of water from surface irrigation projects between the farmers and the time water is released to the different farms. These problems led some farmers to drill their private wells to maintain the required water at the required time.

The estimated total water use is about 12 billion cubic meters. More than $50 \%$ of the ground water is consumed for domestic purposes (Table 5 and Table 6) [31].

Alsam et al. [31] also calculated exploitable groundwater resources. The quantity of ground water with salinities of $1-3$ and $5-10 \mathrm{~g} / \mathrm{l}$ that can be used for irrigation and watering livestock about $3.8 \times 10^{9}$ and $2.25 \times 10^{9}$ $\mathrm{m}^{3} /$ year respectively. The quantity of more saline ground water $(10 \mathrm{~g} / \mathrm{l})$ that can be used for industrial purposes is about $1.54 \times 10^{9} \mathrm{~m}^{3} /$ year (Figure 7).

In general, investment and optimal use of groundwater in Iraq is still at the beginning stage and does not exceed $5 \%$.

\begin{tabular}{|c|c|c|c|c|c|c|c|c|c|c|c|}
\hline \multirow{2}{*}{$\begin{array}{l}\text { Aquifer } \\
\text { No. }\end{array}$} & \multirow{2}{*}{$\begin{array}{l}\text { Total } \\
\text { Area } \\
\mathrm{Km}^{2}\end{array}$} & \multirow{2}{*}{$\begin{array}{l}\text { Modulus } \\
1 / \mathrm{s} \mathrm{km}^{2}\end{array}$} & \multirow{2}{*}{$\begin{array}{c}\text { Resource } \\
1 / \mathrm{s}\end{array}$} & \multicolumn{2}{|c|}{ Less than $1 \mathrm{~g} / \mathrm{s}$} & \multicolumn{2}{|c|}{$1-3 \mathrm{~g} / \mathrm{s}$} & \multicolumn{2}{|c|}{$3-5 \mathrm{~g} / \mathrm{s}$} & \multicolumn{2}{|c|}{$5-10 \mathrm{~g} / \mathrm{s}$} \\
\hline & & & & Area $\mathrm{km}^{2}$ & $\begin{array}{c}\text { Resource } \\
\text { l/s }\end{array}$ & Area km² & $\begin{array}{c}\text { Resource } \\
\text { l/s }\end{array}$ & Area km² & $\begin{array}{c}\text { Resource } \\
1 / \mathrm{s}\end{array}$ & Area $\mathrm{km}^{2}$ & $\begin{array}{c}\text { Resource } \\
\text { l/s }\end{array}$ \\
\hline 1 & 12,300 & 0.75 & 9225 & 0 & 0 & 0 & 0 & 0 & 0 & 0 & 0 \\
\hline 2 & 1000 & 0.5 & 5000 & 3300 & 1650 & 0 & 0 & 0 & 0 & 0 & 0 \\
\hline 3 & 43,300 & 0.5 & 21,650 & 6400 & 3200 & 0 & 0 & 0 & 0 & 0 & 0 \\
\hline 4 & 31,800 & 0.5 & 15,900 & 0 & 0 & 6300 & 3150 & 5600 & 2800 & 0 & 0 \\
\hline 5 & 61,200 & 0.35 & 21,420 & 0 & 0 & 31,700 & 11,095 & 900 & 315 & 0 & 0 \\
\hline 6 & 18,400 & 0.25 & 4600 & 7700 & 1925 & 0 & 0 & 0 & 0 & 0 & 0 \\
\hline 7 & 21,900 & 0.4 & 8760 & 1300 & 520 & 13,100 & 5240 & 5600 & 2240 & 1000 & 400 \\
\hline 8 & 6400 & 0.5 & 3200 & 0 & 0 & 2700 & 1350 & 1500 & 750 & 2200 & 1100 \\
\hline 9 & 40,100 & 1 & 40,100 & 0 & 0 & 21,700 & 21,700 & 11,300 & 11,300 & 2900 & 2900 \\
\hline 10 & 79,300 & 0.75 & 59,475 & 0 & 0 & 200 & 150 & 23,400 & 17,550 & 55,500 & 41,625 \\
\hline 11 & 37,600 & 2 & 75,200 & 0 & 0 & 10,800 & 21,600 & 14,600 & 29,200 & 1700 & 3400 \\
\hline 12 & 10,600 & 3 & 31,800 & 3100 & 9300 & 1200 & 3600 & 1600 & 4800 & 0 & 0 \\
\hline 13 & 40,700 & 2.5 & 101,750 & 24,300 & 60,750 & 2000 & 5000 & 1200 & 3000 & 0 & 0 \\
\hline 14 & 24,500 & 5 & 122,500 & 24,500 & 122,500 & 0 & 0 & 0 & 0 & 0 & 0 \\
\hline
\end{tabular}


Table 6. The total dynamic reserves of water in three categories (domestic, irrigation and livestock and unusable) [31].

\begin{tabular}{ccccc}
\hline \multicolumn{5}{c}{ Total Amount of Ground Water (Billions of Cubic meters) and Water Use } \\
\hline Sub Province & Aquifer No & Domestic1 g/s & Irrigation \& Livestock 1 - 3 g/s & Unusable 3 - 5 g/l \\
\hline Western desert & $1,2,3,4,5,7,8$ & 0.23 & 1.66 & 0.63 \\
Jezera & 9 & 0 & 0.13 & 0.68 \\
Baiji-Tib & 11 & 0 & 0.55 & 0.92 \\
Baghdad Basra & 10 & 0 & 0 & 0.004 \\
Foothill zone & 12,13 & 2.21 & 1.48 & 0.270 \\
High folded zone & 14 & 3.86 & 0 & 0 \\
Total & - & 6.3 & 3.82 & 2.504 \\
\hline
\end{tabular}

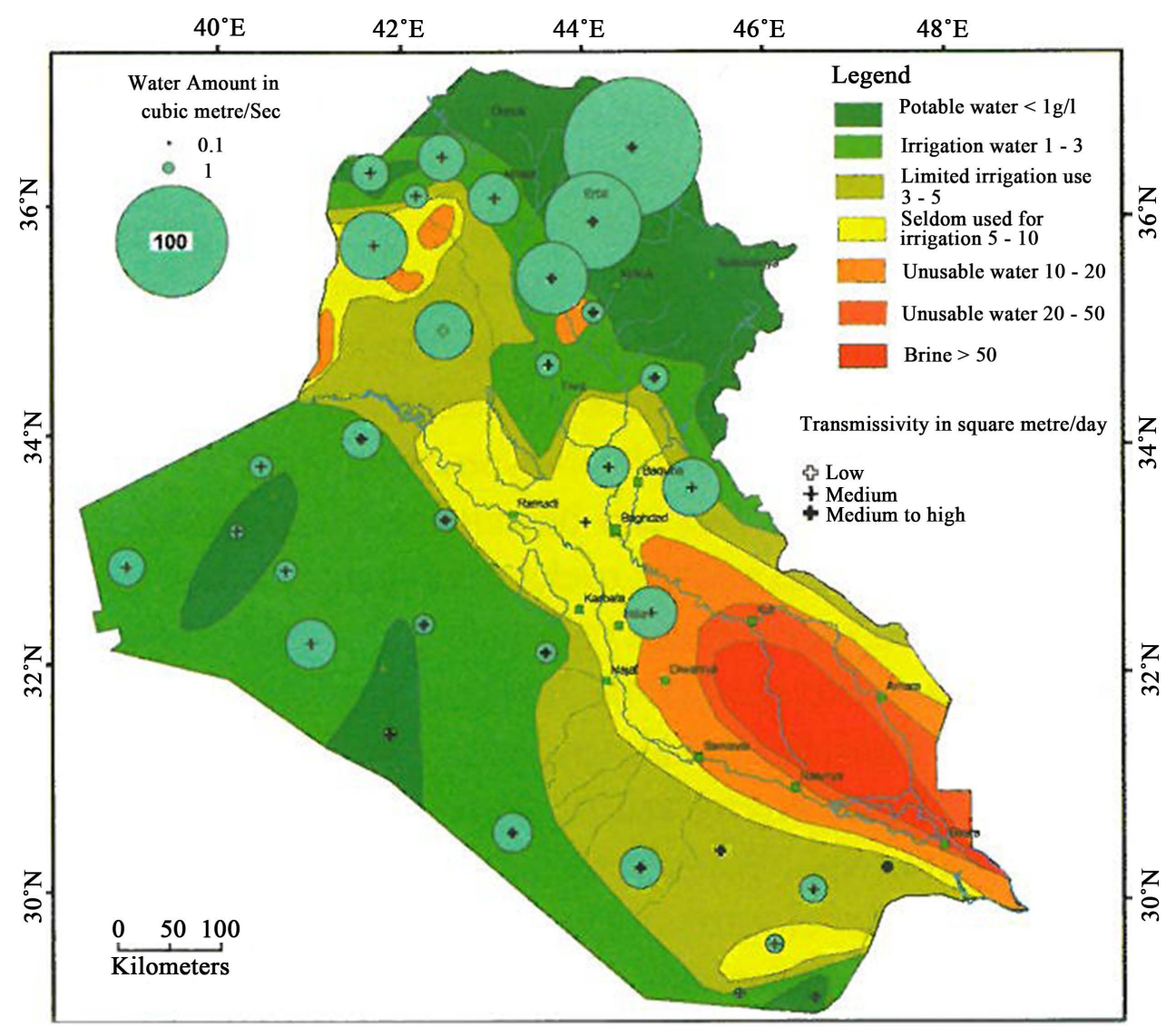

Figure 7. Water use map showing salinity zones and water amount in cubic meters per second as scale points [32].

\subsection{Irrigation Projects}

Irrigation, since the dawn of civilization about 7000 years ago has been an important base for agriculture in Mesopotamia, known as Iraq now. The only source for irrigation water in Iraq was from the Tigris and Euphrates rivers. The nature of these rivers' topography and climate imposed great problems on irrigation practices since its inception. These rivers are renowned for their dramatic spring floods and tremendous amounts of silt they carry. Furthermore, the plains of the country are very flat and poorly drained. As a consequence, the region suffered from persistent problems of poor soil, drought, and catastrophic flooding, silting and soil salinity.

The flooding from the two rivers usually peaks in March and May. This is too late for winter crops and too early for summer crops. In addition, the flow of the rivers varies considerably every year. The floods are usually too 
intensive which instigated some scholars to base numerous flood legends on it, e.g. the Gilgamesh Epic. Conversely, years of flooding make irrigation and agriculture difficult. This made people to opt to water storage and flood control as well as irrigation. In order to overcome the difficulty of frequent flooding, irrigation canals were dredged regularly to overcome rapid silt build up threatening to choke these canals. A more insidious problem to overcome was the draining off of flood water which had the tendency for washing salt build up in the soil. To overcome this situation, the Euphrates River was used as a supply and the Tigris channel as drain.

During Sumerian time each city used to build its own irrigation canals. The cities were originally administrative centers, marketing centers and defensive centers all connected to local irrigation schemes. Through the past history of Iraq engineers built very large weirs and diversion dams to create reservoirs and to supply canals that carried water for long considerable distances.

The prosperity of irrigation projects continued through the Islamic period. During the period 762 AD to 1258 $\mathrm{AD}$, irrigation schemes were renovated and greatly extended. Water was carried out of the River Euphrates and led into parallel canals across the Mesopotamia plain where huge areas were irrigated. There was extensive salinity in the south. When the central government began to fail about the twelfth century the canals became silt choked, irrigation systems deteriorated and the land became more saline. In 1200 AD massive flood destroyed the whole system where the Tigris and the Euphrates changed their courses, cutting off most of the water supply to irrigation canals. What remained of the system collapsed in 1258 AD when the Mongols devastated Iraq. Iraq has remained as a desert for more than 600 years.

Not until the twentieth century did Iraq make a concerted effort to restore its irrigation and drainage network and to control seasonal flooding. Different governments constructed several large dams and river control projects, rehabilitated old canals and built new irrigation schemes. Examples of major projects are given in Table 7. Barrages were constructed on both rivers to divert water into natural depressions so that floods could be controlled, In addition, water can be used for irrigation after the rivers peaked in the spring.

\begin{tabular}{|c|c|c|c|}
\hline & Project & Location & Year Established \\
\hline 1 & Nadiem Basha Embankment & E. Baghdad & 1911 \\
\hline 2 & Hindiyah Barrage & Hindiyah & 1913 \\
\hline 3 & Submerged Diyala Weir & N. Mukdadiyah & 1928 \\
\hline 4 & Fist discharge recording station & Baghdad & 1930 \\
\hline 5 & Diayala Irrigation Project & N. Baghdad & 1937 \\
\hline 6 & Kut Barrage & Kut & 1939 \\
\hline 7 & Dokan Dam & L. Zab River & 1954 \\
\hline 8 & Ramadi Barrage & Ramadi & 1956 \\
\hline 9 & Musaiyab Irrigation Project & Musaiyab & 1957 \\
\hline 10 & Derbendikhan Dam & Diyala River & 1961 \\
\hline 11 & Damlage Irrigation Project & Damlage & 1963 \\
\hline 12 & Dibis Dam & L. Zab River & 1965 \\
\hline 13 & Ishaki Irrigation Project & Ishaki & 1966 \\
\hline 14 & Small desert dams & W. Desert & 1970 \\
\hline 15 & Saddam Irrigation Project & Kirkuk Gov. & 1971 \\
\hline 16 & Great Drainage Canal & Central Iraq & 1972 \\
\hline 17 & Husainiyah Irrigation Project & Husainiyah & 1974 \\
\hline 18 & Kifil-Shanafigah Irrigation Project & Kifil-Shanafigah & 1975 \\
\hline 19 & Shabja and Sawari dams & W. Desert & 1976 \\
\hline 20 & Hemrin Dam & Diyala River & 1985 \\
\hline 21 & Mosul Dam ( Saddam Dam ) & Mosul & 1986 \\
\hline 22 & Qadisiyah Dam & R. Euphrates & 1986 \\
\hline 23 & Duhok Dam & Duhok & 1985 \\
\hline 24 & Adaim Dam & Adaim & 1999 \\
\hline
\end{tabular}


Some dams were built on the tributaries of the River Tigris and on the main rivers as well. The total storage capacity of those dams was 13.7 cubic kilometers in the 1970s. During the 1980s a dam construction program was adopted. Mosul dam (Saddam dam) on the Tigris was constructed with a total storage capacity of 11.1 cubic kilometers. Qadisiaya dam was built on the Euphrates. Desert dams were also built having a storage capacity of 0.5 cubic kilometers, several other dams, such as the Bakhma dam on the Greater Zab river with 17.1 cubic kilometers storage capacity and the Badash dam on the Tigris river with 0.5 cubic kilometers, were under construction till 1990. The construction stopped after the first Gulf war. In addition to these dams two storage lakes had been created. The Tharthar (storage capacity 85 cubic kilometers) and Habbaniya which can the filled and drains into the lower reaches of the Euphrates.

To increase water transport efficiency, minimize losses and water logging and improve water quality, a number of new canals were constructed mainly in the southern part of Iraq. The most important was the "Third River" which functions as a drainage water of more than 1.5 million hectares of agricultural land extending north Bashdo to the gulf . This river which runs between the Tigris and the Euphrates was completed in 1992 with a total length of $565 \mathrm{~km}$ and a discharge of $210 \mathrm{~m}^{3} / \mathrm{s}$.

Long term data show that Iraq allocates $92 \%$ of its water resources for the agricultural sector. The overall cultivated area in Iraq mounts to 5,450,000 hectares of which 2,300,000 hectares are irrigated land. During 1990, water withdrawal was estimated to be 42.8 cubic kilometers of which $92 \%$ was used for agriculture, $3 \%$ for domestic supplies and $5 \%$ for industrial use. Irrigation potential in 1990 was estimated at over 5.5 million hectares of which 63\% was in the Tigris basin, 35\% in the Euphrates basin and 2\% in Shatt Al-Arab basin, As far as soil quality in concerned, 6 million hectares were classified as excellent, good or moderately suitable for flood irrigation. With the increase of the volume of regulated flow the irrigation potential increased significantly. The total water managed area reached 3.5 million hectares which is equipped with partial control irrigation. The areas irrigated from surface water are about 3.3 million hectares of which not more than $30 \%$ in Shatt Al-Arab, the remainder are within Tigris and Euphrates basins. It is noteworthy to mention that all these areas are not currently irrigated since a large part has been abandoned due to water logging and salinity. It had been estimated that only 1,936,000 hectares were actually irrigated in 1993.

As far as irrigation using ground water resources, it was estimated that 220,000 hectares were irrigated using 18,000 wells. Furthermore about 8000 hectares were equipped for micro-irrigation, but these techniques were not used. During the year 2000, the total renewable water resources in Iraq were 75.42 cubic kilometers. Irrigation water requirements were 11.2 cubic kilometers while water use efficiency in percentages was $28 \%$. Water withdrawal for agriculture reached 39.38 cubic kilometers and water withdrawal as percentage of renewable water resources were $52 \%$.

Strategic crop growing activities during the 1990s show that 224,490 hectares were of irrigated wheat with an average yield of 2.7 tons/ha, while rain fed wheat areas were of the order of 508,620 hectares, with an average yield of 1.7 tons/ha. As far as barely is concerned, there were 200,700 hectares of irrigated barely with an average yield of 1.8 tons/ha. Rain fed barely areas were 323,730 hectares with an average yield of 1.3 tons/ha. Other craps like rice, vegetables, and corn and date trees were also irrigated.

\subsubsection{Irrigation Projects on the River Tigris}

The most important projects are:

\section{A. Existing projects:}

- Hemrin Dam: This dam was constructed on the river Diyala $10 \mathrm{~km}$ upstream the Siddor weir. The storage capacity of the dam is $3.95 \times 109 \mathrm{~m}^{3}$ with a total drainage area of $3370 \mathrm{~km}^{2}$.

- Mosul Dam: This was used to be referred to as the Saddam dam. It was constructed on the River Tigris $58 \mathrm{~km}$ upstream Mosul city. The maximum storage capacity is $14.45 \times 109 \mathrm{~m}^{3}$. The drainage area of the dam is $50,200 \mathrm{~km}^{2}$. The total length of the reservoir is $75 \mathrm{~km}$.

- Fars Dam (Bakhma): This dam is located on the Greater Zab River. The storage capacity reaches $17.1 \times 109$ $\mathrm{m}^{3}$. The construction of the first stage of this dam is already finished but nothing was done after 1990 due to the political situation.

- Dokan Dam: This dam is located on the Lower Zab River 60 km west of Sulaymaniya city. Its storage capacity is $7.9 \times 109 \mathrm{~m}^{3}$. The area of the reservoir is $50 \mathrm{~km}^{2}$.

- Derbendikhan Dam: This dam is located on the upper reaches of River Diyala with a total storage capacity of $3.0 \times 109 \mathrm{~m}^{3}$. The area of the reservoir is $121 \mathrm{~km}^{2}$. 
- Kut Barrage: This barrage was constructed on the River Tigris near Kut city to regulate the water. Two irrigation canals take water from this scheme (Gharaf, Dijalah).

- Duhok Dam: is located on Rubar River near Duhok city. The storage capacity of the dam is $50 \times 106 \mathrm{~m}^{3}$.

- Third River (Saddam River): This River is to collect saline water from irrigation projects on the Tigris and Euphrates Rivers. Large number of drainage canals supplies this river with water. At Nasiriyah it crosses the River Euphrates through a tunnel under the bed of the Euphrates River. It is about $550 \mathrm{~km}$ long. In its upper parts its discharge is $40 \mathrm{~m}^{3} / \mathrm{s}$ and increase to $350 \mathrm{~m}^{3} / \mathrm{s}$ in the lower reaches.

- Adhaim Dam: This dam was constructed on Adhaim River in 1999. Its storage capacity is $1.5 \times 109 \mathrm{~m}^{3}$. The Adhaim Dam project is located about $70 \mathrm{~km}$ upstream from the Adhaim's confluence with the Tigris. It diverts water at the confluence of the Adhaim and the Aq Su Rivers.

- Tharthar Scheme: Tharthar depression is located $65 \mathrm{~km}$ northwest Baghdad city between the Tigris and the Euphrates Rivers. The length and width of the depression is $100 \mathrm{~km}$ and $40 \mathrm{~km}$ respectively. Its total storage capacity is $85 \times 109 \mathrm{~m}^{3}$. This scheme is composed of:

Samara Regulating Barrage, which is a concrete structure located opposite Samara city. Intake of Ishaki irrigation canal is located upstream this regulating dam. The regulator barrage converts flood water to the Tharthar intake canal.

Protection Embankments, which extends to a distance of $62 \mathrm{~km}$, and Intake Canal. The embankments are earth fill type for protection from floods upstream the Samara barrage. Flood water is taken through 36 gates. Each gate is $12 \mathrm{~m}$ wide. It can allow $9000 \mathrm{~m}^{3} / \mathrm{s}$ when the water level upstream the Samara regulator is $69 \mathrm{~m}$ above sea level.

\section{B. Proposed projects}

- Upper Adhaim Dams: These are a number of small dams to be constructed on the tributaries of River Adhaim.

- Marhala Dam: To be constructed on the Taini tributary of the Lower Zab River.

- Razka Dam: To be constructed on the Razka valley to supply the Greater Zab River with water.

- Jumurka Dam: To be constructed on the Jumurka valley to supply the Greater Zab River with water.

\subsubsection{Irrigation Projects on the River Euphrates}

\section{Dams:}

- Qadisiyah Dam: It is located near Haditha city with a storage capacity of $9.98 \times 10^{9} \mathrm{~m}^{3}$ with $0.24 \times 10^{9} \mathrm{~m}^{3}$ of dead storage.

- Habaniyah Lake: Located west the Euphrates River near Faluja. Its storage capacity is $3.3 \times 10^{9} \mathrm{~m}^{3}$.

- Razaza Lake: It is located south of Habaniyahlake with a dead storage capacity of $40 \times 10^{9} \mathrm{~m}^{3}$.

Dams constructed within the western desert:

- Rutbah dam: It is located on Horan valley $30 \mathrm{~km}$ from Rutbah city. Its storage capacity is $32 \times 10^{9} \mathrm{~m}^{3}$.

- Waleed project: Two small dams constructed southwest of Rutbah.

- Small Rutbah dam: Located on one of Horan valley's tributaries.

- Aghri dam: Located on the Aghri valley.

- Ebliah dam: Located on the Ebliah valley northeast of Rutbah.

- Husainiyah dam: Located on the Husainiyah valley northeast of Rutbah.

- Sury dam: Located south of Rutbah.

- Shibiga dam: Located southwest of Rutbah.

- Waleg dam: Located on the Waley valley.

- Kaieda dam: Located on the Kaeida valley.

- Asak dam: Located on the Asak valley.

- Amura dam: Located on the Amura valley.

- Um Turfat dam: Located on the Um Turfat valley.

- Rahaliya dam: Located on the Rahaliya valley.

- Ruwdha dam: Located on the Ruwdha valley.

- Mahmaja dam: Located on the Mahmaja valley.

- Abla dam: Located on the Abla valley.

- Jasan dam: Located on the Jasan valley.

- Minyama dam: Located on the Minyama valley.

\section{Regulating schemes}

- Ramadi barrage: Located near Ramadi. Its discharge capacity is $3600 \mathrm{~m}^{3} / \mathrm{s}$. 
- Warar regulator: Its discharge capacity $2800 \mathrm{~m}^{3} / \mathrm{s}$.

- Majara regulator: Its discharge capacity $850 \mathrm{~m}^{3} / \mathrm{s}$.

- Dhiban regulator: Its discharge capacity $800 \mathrm{~m}^{3} / \mathrm{s}$.

- Faluja regulator: Its discharge capacity $3600 \mathrm{~m}^{3} / \mathrm{s}$.

- Hindiyah regulator: Its discharge capacity $2500 \mathrm{~m}^{3} / \mathrm{s}$.

- Shatt Alhila regulator: Its discharge capacity $326 \mathrm{~m}^{3} / \mathrm{s}$.

- Kufa regulator: Its discharge capacity $1400 \mathrm{~m}^{3} / \mathrm{s}$.

- Mushkhab regulator: Its discharge capacity $750 \mathrm{~m}^{3} / \mathrm{s}$.

- Abasiya regulator: Its discharge capacity $1200 \mathrm{~m}^{3} / \mathrm{s}$.

- Shamiya regulator: Its discharge capacity $1100 \mathrm{~m}^{3} / \mathrm{s}$.

- Ghalyun regulator: Its discharge capacity $250 \mathrm{~m}^{3} / \mathrm{s}$.

\section{The Problem}

Scarcity of water resources in Iraq can be attributed to two main reasons:
A) External
B) Internal

\subsection{External}

\subsubsection{Climate Change}

MENA region with its arid climate is expected to be the most vulnerable in the world to the potential impacts of climate change [33]-[35]. The region is expected to suffer from higher temperatures and intense heat waves effecting inhabitants and the crops. Recent work for long term predictions of temperature and rainfall had indicated that the former will be increasing in Iraq while the latter will be decreasing (Figure 8 and Figure 9) [17] [36][40].

IPCC [34] observed that there are different impacts on the physical and biological systems due to climatic change. Higher air temperatures will affect marine ecosystems and fisheries, less but more intense rainfall, causing both more droughts and greater flooding, sea level rise, more intense cyclones, new areas exposed to dengue, malaria, and other vector and waterborne diseases [1]. New record high had been noticed in some MENA countries including Iraq $\left(52.0^{\circ} \mathrm{C}\right)[41]$.
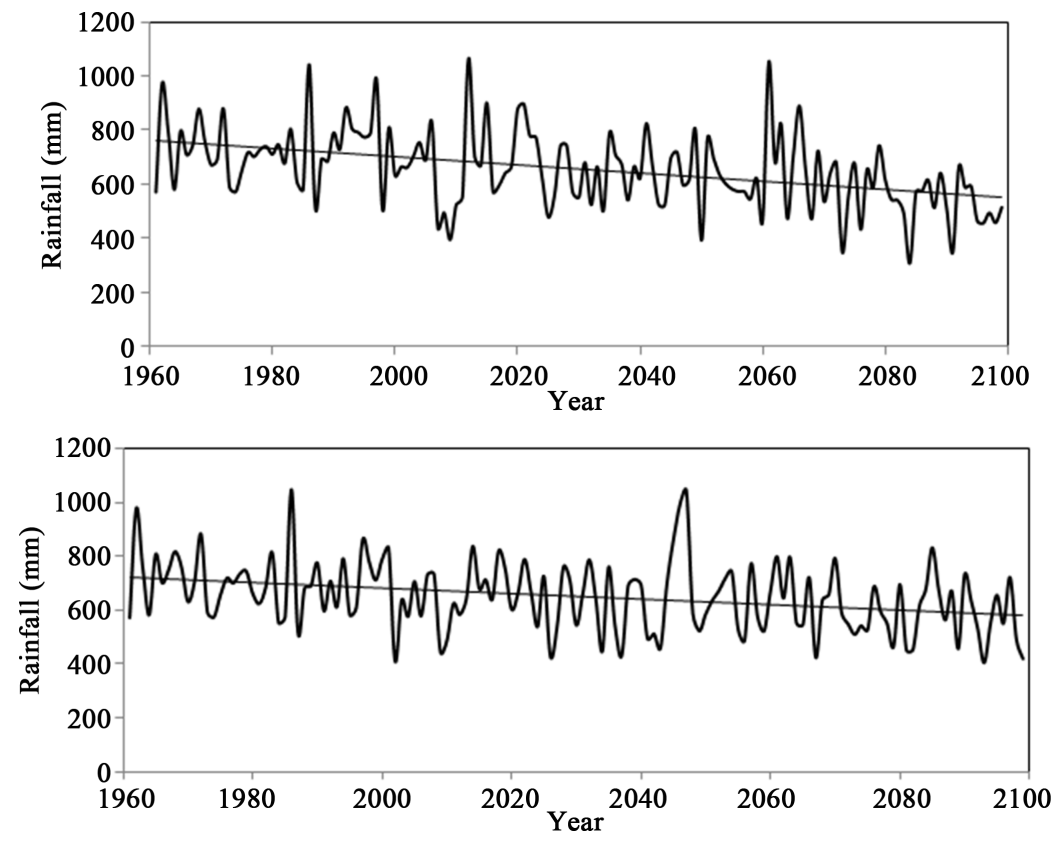

Figure 8. Average annual rainfall at northeast of Iraq for A2 scenario (upper) and B2 scenario (lower) compared with control period [36]. 

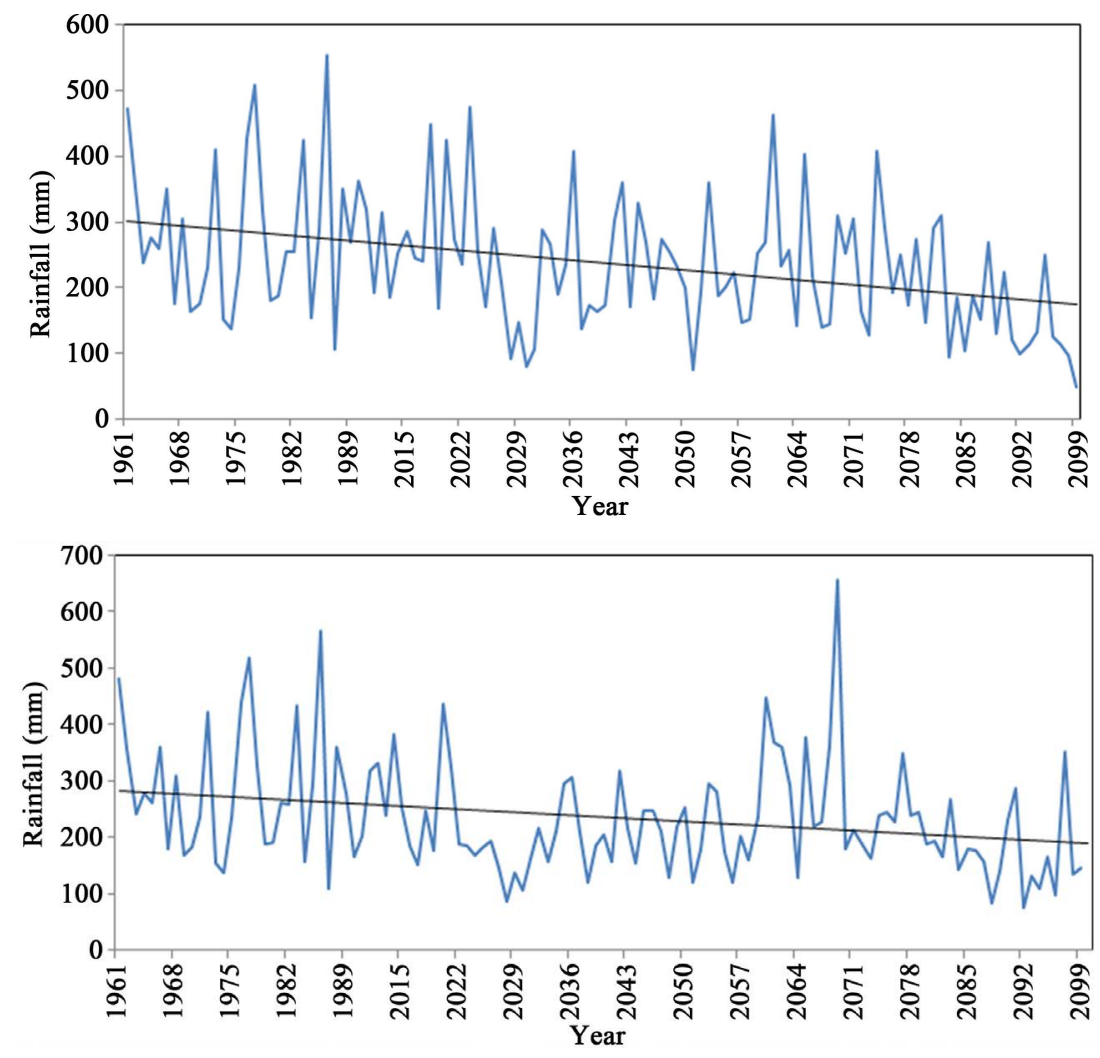

Figure 9. Average annual rainfall northwest Iraq for A2 scenario (upper) and B2 scenario (lower) compared with control period [37].

As a consequence of global warming, the size of oceans had expanded and sea level rise increased from $1.8 \mathrm{~mm}$ annually (1961-2003) to $3.1 \mathrm{~mm}$ (1993-2003) [34] [42]. AFED [33] and Dasgupta et al. [43], reported that the Gulf at its northern tip north of Kuwait and south of Iraq (Shatt el Arab) will be effected by sea level rise. Despite the limited coastline Iraq has on the Gulf region, the vulnerable low land areas extend as far inland as near Baghdad. In addition, Arnell [44] indicated that the flow of rivers in the Middle East will be decreased due to climatic changes at the end of the 21st century.

In MENA region will be warmer, drier and more variable where the temperatures are likely to rise $0.3^{\circ} \mathrm{C}$ or $0.4^{\circ} \mathrm{C}$ per decade. This is 1.5 times faster than the global average. Most of North Africa and the eastern Mediterranean will become drier [41]. Water supply and agriculture will be effected [45] [46]. Iraq will be greatly affected due to the fact that its one-third of cereal production (wheat and barley) is produced under rain-fed conditions at north of Iraq [47] [48]. Droughts and floods will increase as a result of increasing temperature [49]-[52]. This will affect the agriculture [46].

Dust storms are expected to be more frequent [33] [53] [54]. In addition, the precipitation is to decrease about $20 \%$ with temperature increase of $3^{\circ} \mathrm{C}$ to $5^{\circ} \mathrm{C}$ [55] (Elasha, 2010) and runoff will be reduced by $20 \%$ to $30 \%$ in most of MENA region by 2050 [56] (Milly et al., 2005).

\subsubsection{Shared Catchments}

The Euphrates, Tigris and Shatt Al-Arab Rivers catchments are shared between the countries neighboring Iraq as shown in Figure 10 and Table 8 and Table 9. Due to the fact that all the major rivers in Iraq are shared with neighboring countries several agreements were signed with neighboring countries [2] but none of them had been put into practice (see as an example Burleson [57]).

During the 1970s Syria and Turkey started to construct dams on the Euphrates and Tigris Rivers which caused a major decrease in the flow of the rivers [1] [22] as well as deterioration of the quality of their water [58].

The situation became very tense both in 1975 and 1998 and war was narrowly averted due to water shortages after building dams [61]. 


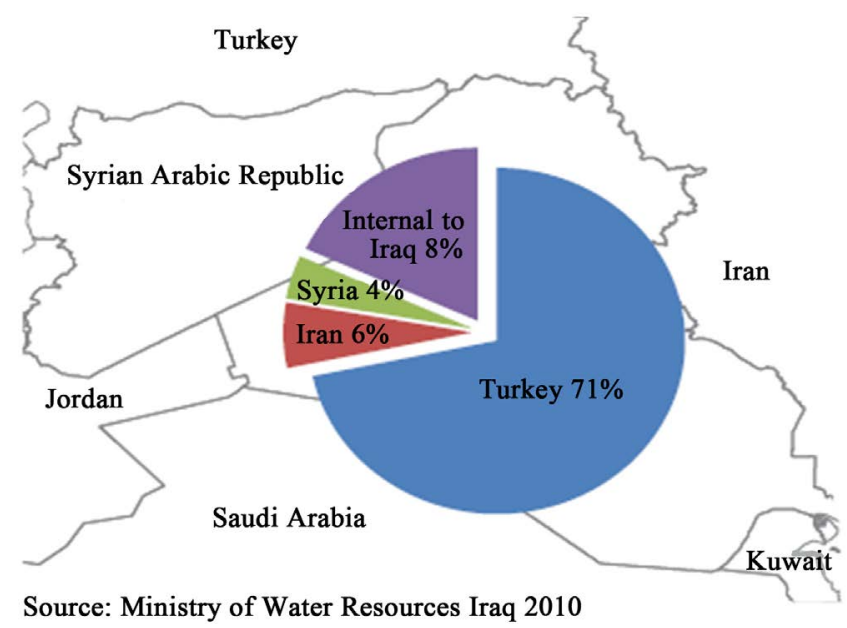

Figure 10. Source of water for the Tigris and Euphrates Rivers [59].

Table 8. Rivers of Iraq and riparian countries.

\begin{tabular}{ccc}
\hline River & Riparian Countries & Main Shared Tributaries \\
\hline \multirow{2}{*}{ Euphrates } & Sajur \\
& Iraq, Jordan, Saudi Arabia, Syria, Turkey & Jallab/Balikh \\
& & Khabour \\
Tigris & Iraq, Syria, Turkey, Iran & FeeshKhabour \\
& & Greater Zab \\
& & Lesser Zab \\
Shatt Al-Arab & Diyala \\
& Iraq, Iran & Tigris \\
& & Euphrates \\
& Karun \\
& & Karkheh \\
\hline
\end{tabular}

Table 9. Contribution of countries to Euphrates and Tigris Rivers [60].

\begin{tabular}{|c|c|c|c|c|c|c|}
\hline \multicolumn{2}{|c|}{ Tigris and Euphrates Rivers } & Turkey & Iraq & Syria & Iran & Total \\
\hline \multirow{2}{*}{ Discharge } & $\%$ & 78.1 & 8.1 & 0.5 & 13.3 & \\
\hline & Billion m³/year & 65.7 & 6.8 & & 0.5 & 84.2 \\
\hline \multirow{2}{*}{ Drainage area } & $\%$ & 20.5 & 46.0 & 9.0 & 19.0 & \\
\hline & Billion m³/year & 170,000 & 469,000 & 77,000 & 37,000 & 819,000 \\
\hline \multirow{2}{*}{ River length } & $\%$ & 33.5 & 51.0 & 15.5 & - & \\
\hline & $\mathrm{km}$ & 1630 & 2478 & 754 & - & 4862 \\
\hline
\end{tabular}

\section{Turkish Water Projects}

In 1977, the Turkish government set a huge project referred to as Southeastern Anatolia Project (GAP) [62] (GAP, 2006). The component of the project includes 22 dams and 19 hydraulic power plants (Table 10) which are supposed to irrigate $17,000 \mathrm{~km}^{2}$ of land [63] (Unver, 1997). The project is supposed to develop the southeastern provinces which cover $9.7 \%$ of the total area of Turkey which forms $20 \%$ of the agricultural land of the country. The overall volume of water to be captured is about $100 \mathrm{~km}^{3}$ (while the required water to irrigate the supposed area is about $29 \mathrm{~km}^{3}$ ) which is three times more than the overall capacity of Iraq and Syrian reservoirs. Despite the continuous claims of the Turkish Government that GAP is purely development project, it seems that there are number of internal and external goals involved [64]-[69]. When GAP project is completed, then $80 \%$ of the Euphrates water will be controlled by Turkey [70]-[72]. 
Table 10. Dams of the GAP project in Turkey.

\begin{tabular}{ccc}
\hline River Basin & Name of the Dam & Year of Completion \\
& Ataturk & 1992 \\
Birecik & 2000 \\
Camgazi & 1998 \\
Hancagrz & 1988 \\
Karakaya & 1987 \\
Karkamis & 1999 \\
Buykcay & Suggested \\
& Catallepe & Suggested \\
Gomikan & Suggested \\
& Kahta & Suggested \\
& Kayacik & Suggested \\
& Kemlin & Suggested \\
& Koeali & Suggested \\
& Sirmtas & Suggested \\
& Batman & 1998 \\
& Dicle & 1997 \\
& Kralkizi & 1997 \\
& Cizre & Suggested \\
Tigris & Garzan & Suggested \\
& Kayser & Suggested \\
& Ilisu & Under construction \\
& Silvan & Suggested \\
\hline
\end{tabular}

When Ilisu dam on Tigris River is operating then, Iraq will receive only $9.7 \mathrm{~km}^{3}$ [73]. This implies that $47 \%$ of the river flow will be depleted. This in turn means that 696,000 ha of agricultural land will be abandoned due to water scarcity [1] [22]. Recent reports state that Tigris and Euphrates rivers will be completely dry by 2040 [20].

\section{Syrian Water Projects}

Syria built three main dams (Table 11) along Euphrates River with a total storage capacity of $16.1 \mathrm{~km}^{3}$ for irrigation and electricity generation.

Syria used to receive $21 \mathrm{~km}^{3} /$ year of the Euphrates water prior 1990 which dropped to $12 \mathrm{~km}^{3}$ in 2000 onward (40\% reduction). As far as Iraq is concerned, the volume of water received dropped from $29 \mathrm{~km}^{3}$ before 1990 [74] to $4.4 \mathrm{~km}^{3}$ (85\% reduction) now. Due to this reduction in water shares, the agricultural used land in both countries had been reduced from 650,000 ha to 240,000 ha. In addition, the quality of water deteriorated due to back water irrigation directed toward the main channel in its upstream reaches [1] [22].

Syria is planning to double its irrigated area (740,000 ha). This will increase its water withdrawal from $5 \mathrm{~km}^{3}$ to $9 \mathrm{~km}^{3}$ [75] and will cause:

- Diminishing of water for agriculture.

- Land degradation due to expected high salinity.

- More drying of the marshes causing more ecological damage.

- Further deterioration of the already bad water quality of the Euphrates (TDS is $1800 \mathrm{mg} / \mathrm{L}$ now).

- Less hydropower generation.

- Rising the risk of regional conflict

- Demographical implications where farmers and fishermen will leave their homes.

- Lower groundwater levels

\section{Iranian Water Projects}

In addition to the above, Iran had recently diverted all perennial valleys running toward Iraq inside Iran. Furthermore, water of Karkha and Karun Rivers had been almost completely diverted inside the Iranian borders and no water is contributing to Shatt Al-Arab River from these tributaries (Figure 4 and Figure 6).

Shatt Al-Arab River is formed after the confluence of Tigris and Euphrates Rivers at Qurnah in Iraq. Its total length is $192 \mathrm{~km}$ and its width is about $300 \mathrm{~m}$ near Qurnah and increases downstream to $700 \mathrm{~m}$ near Basra city and to about 850 m near its mouth at the gulf area. Karun and Karkha Rivers usually contributes 24. 5 and 5.8 billion cubic meters (BCM) annually respectively (Figure 6). This forms about $41 \%$ of the water of Shatt AlArab. The decrease of the water discharge of the Tigris and Euphrates Rivers and the diversion of the water of Karun and Karkha tributaries caused the salinity to increase to $2408 \mathrm{mg} / \mathrm{l}$ in 2011 [2]. 
Table 11. Dams of Euphrates River in Syria.

\begin{tabular}{ccc}
\hline Dam & Storage Capacity $\left(\mathrm{km}^{3}\right)$ & Year of Operation \\
\hline Forat & 14.163 & 1978 \\
Baath & 0.9 & 1989 \\
Teshreen & 1.883 & 2000 \\
Total & 16.943 & \\
\hline
\end{tabular}

In addition, Iran and Kuwait signed an agreement in which Iran committed to supplying Kuwait with drinking water for a period of 30 years at a cost of USD 2 billion. About 300 MCM of water from the Karkheh River is to be conveyed to Kuwait through a 540-km pipeline [2]. Furthermore, Haweizeh Marsh used to extend over a vast area of 300,000 ha (in average conditions). Iran constructed a levy running along the international border through the Haweizeh Marsh which significantly reduced freshwater contribution from the Karkheh River and further jeopardize the subsistence of this important ecosystem [2].

\subsection{Internal}

The population growth rate in Iraq is very high (3.6\%) where it was 20.4 million in 1995 and reached 32 million in 2013 [2]. The population density however, varies from 5 to 170 in habitants $/ \mathrm{km}^{2}$ in western desertic and the central part of the country respectively [1] [22]. One third of the inhabitants are involved in agricultural activities [76]. For this reason, most of the water is consumed in agricultural practices (90\%) followed by industry (6\%) and domestic uses (4\%) [6] [11] [75]. About $38.5 \mathrm{~km}^{3}$ of water was used for agricultural purposes in 1990since the percentage of the agricultural land is 19\% - 25\% (8.2 - 11.5 million ha) of the total area of Iraq. Recently, it is believed that this amount had been decreased slightly to 85\% [1] [22]. This amount is used for an area of 8.2 million ha, which forms $70 \%$ of the total cultivable area. About $40 \%-50 \%$ of this area is irrigable, while the remainder is rain fed and only $7 \%$ is of the area is supplied by ground water. Considering the soil resources, about 6 million hectares are classified as excellent, good or moderately suitable for flood irrigation. The irrigation potential is 63\%, 35\% and 2\% for the Tigris, Euphrates and Shat Al-Arab Rivers respectively. Irrigation consumptive use reached $39 \mathrm{~km}^{3}$ in 1991 and in 2003/2004 it was $22 \mathrm{~km}^{3}$ equivalents to $44 \mathrm{~km}^{3}$ of water derived, assuming 50\% irrigation efficiency. Real efficiency might be $25 \%$ - 35\%. Existing data estimates that the contribution of the agricultural sector was only $5 \%$ of Gross Domestic Product (GDP) which is usually dominated by oil (more than $60 \%$ ). About $20 \%$ of the labour force is engaged in agriculture [1] [22].

It should be mentioned however, that the demand of the industrial sector decreased with the progress idling of the industrial capacity. Hydropower use including the evaporation from reservoirs reaches 10/annum BCM. Potable water usage in Iraq is about 350 liters/capita/day for the urban areas [77] and it used to reach $100 \%$ and $54 \%$ the urban and rural areas in 1991. The situation deteriorated in both quantity and quality afterwards and $33 \%$ of the population do not have access to water and sanitation. Current estimates indicate that water supply to urban areas is $94 \%$ and in rural areas is $67 \%$ [76]. Water services are limited to few hours per day and its quality does not meet WHO standards or Iraqi national water quality standards.

The available water in Iraq is still more than it is compared to the neighbouring countries with exception of Turkey, where it reaches 75 BCM which is equivalent to $2400 \mathrm{~m}^{3}$ per capita per year [20] [78].

To estimate water demand in Iraq, MWR [79] studied this problem so that it can sustain good water quality of the inhabitants. The main facts concerning the water situation in Iraq can be summarized as follow:

In 2011, the demand was about $11 \mathrm{MCM} /$ day in 2011, while the domestic water shortage was $1.7 \mathrm{MCM} /$ day [77]. The goal of the government is to ensure water supplies to 91\% of the population by 2015 [20]. The scenarios given by IMMPW [77] are based on lower on going consumption level from 350 to 200 litter/capita/day and with expected population of more than 34 million in 2015, the potable water demand will range between 8 and $13 \mathrm{MCM} /$ day (Table 12) depending on overall (treating, conveying and distribution) efficiency. An additional 5 BCM of water required in sanitation sector due to the fact that the infrastructure is out of service losses have increased. About $79 \%$ of the population has access to drinking water (92\% in urban and 57\% in rural areas) [80]. In addition, those having access to drinking water it takes about 21 minutes in urban areas (42 minutes in rural areas) to get to the source to bring water for $17 \%$ of all households. The same survey showed that $21 \%$ have no 
Table 12. Expected population and potable water demand for different water shares and different distribution system efficiency.

\begin{tabular}{|c|c|c|c|c|c|c|c|c|}
\hline \multirow{2}{*}{$\begin{array}{l}\text { Water Share } \\
\text { (l/capita/day) }\end{array}$} & \multirow{2}{*}{ Year } & \multirow{2}{*}{$\begin{array}{l}\text { Population } \\
\text { (Million) }\end{array}$} & \multirow{2}{*}{$\begin{array}{c}\text { All Population } \\
\text { Demand (MCM/day) }\end{array}$} & \multirow{2}{*}{$\begin{array}{c}\text { 91\% Population } \\
\text { Demand } \\
\text { (MCM/day) }\end{array}$} & \multicolumn{4}{|c|}{ Real Water Demand (MCM/day) } \\
\hline & & & & & Efficiency $50 \%$ & Efficiency $60 \%$ & Efficiency $70 \%$ & Efficiency $80 \%$ \\
\hline \multirow{2}{*}{350} & 2012 & 32 & 11.2 & 10.192 & 20.384 & 16.98667 & 14.56 & 12.74 \\
\hline & 2015 & 34.98 & 12.243 & 11.14113 & 22.28226 & 18.56855 & 15.9159 & 13.92641 \\
\hline \multirow{2}{*}{250} & 2012 & 32 & 8 & 7.28 & 14.56 & 12.13333 & 10.4 & 9.1 \\
\hline & 2015 & 34.98 & 8.745 & 7.95795 & 15.9159 & 13.26325 & 11.3685 & 9.947438 \\
\hline \multirow{2}{*}{200} & 2012 & 32 & 6.4 & 5.824 & 11.648 & 9.706667 & 8.32 & 7.28 \\
\hline & 2015 & 34.98 & 6.996 & 6.36636 & 12.73272 & 10.6106 & 9.0948 & 7.95795 \\
\hline
\end{tabular}

access to drinking water, $16 \%$ have daily problems, $7 \%$ have weekly problems, $15 \%$ have less than weekly problems and only $41 \%$ have reliable source. The World Bank [75] stated that the efficiency of the distribution network is very poor (32\%) and it is deteriorating with time. For this reason water allocation per capita is decreasing with time since 1980 [81]. Furthermore, the quality of drinking water does not meet WHO standards or Iraqi national water quality standards [82]. Leakage, in both potable water distribution and sewage systems causes high contamination. In view of this situation large number of the population are suffering from various disease [20] [80] [83] [84].

Estimates of the agricultural sector in Iraq indicates that cropped land is about 1.9 million ha in recent years out of 4 million ha arable lands. According to Iraqi Ministry of Planning (MoP), Iraq is planning to increase the agricultural area in 2017 cropped by wheat and barley by $14 \%$ and $21 \%$ respectively [85]. In case all arable land is cropped then the water requirement is 50 BCM, assuming good irrigation efficiency.

Salinity of the soil in Iraq was noticed long time ago since the Sumerians [86] [87]. For this reason the efforts were concentrated since the mid-seventies of the last century to construct drainage projects. The major aims of drainage projects are to prevent water logging, control salinity and acidity as well as increasing cultivable areas [88]. The problem of drainage water intensified with the expansion of drainage of irrigated lands in Turkey and Syria which caused deterioration of the water quality of the two rivers. The Turkish government is planning to 1.8 million ha of the land through the GAP project (of which 270,000 ha is currently operational) while the Syrian government is planning to irrigate 650,000 ha (of which 325,000 ha are already irrigated from the Euphrates River in 2000) [2].

The Iraqi government tried to reduce the salinity in the two rivers by constructing what is referred to as "the third river". This river is $565 \mathrm{~km}$ long and it flows from Baghdad to the Gulf via the KhorZubair Canal. It was completed in 1992 after 30 years of work. It collects drainage water from more than 1.5 million ha of land between the Euphrates and Tigris Rivers. It is to resolve the chronic salinity problem affecting farmland between the two rivers, by collecting saline drainage water and preventing it from flowing into the Euphrates. The canals discharge into southern Hammar Marsh that is fed by the Euphrates and Tigris. About 17 million tons of salt reportedly flowed into the Gulf through the Third River in 1995 [2].

The salinity or Total Dissolved Solids (TDS) in Euphrates River at the Syrian-Iraqi borders is $600 \mathrm{mg} / \mathrm{l}$ which is already higher that the recommended level for irrigation (Figure 11) and it increases to more than $1200 \mathrm{mg} / \mathrm{l}$ (minimum) downstream at Samawah [75] [77]. Tigris River is in better situation relative to the Euphrates River (Figure 12). TDS values of the Tigris water at the Turkish Iraqi border are 280 - $275 \mathrm{mg} / \mathrm{l}$ and it reaches more than $1800 \mathrm{mg} / \mathrm{l}$ in Basra (IMMPW, 2011). The situation might be worse on the tributaries where TDS values in the Diyala River reaches $3705 \mathrm{mg} / \mathrm{l}$ [84] (Jawaheri and Alsahmari, 2009).

Within Iraq, the source of most of the back irrigation water is from irrigation projects (1.5 million ha) that are located in the central and southern parts of the country. Back irrigation water from these projects is directed to the main outfall drain which drains to the gulf in order to reduce the soil salinity [89]. Despite the presence of these drainage measures, the salinity increases downstream along the courses of the two rivers in conjunction with decreases in their discharges (Figure 13 and Figure 14). This situation overstressed the agricultural sector in the southern Iraq. Tracking the changes of Tigris River's salinity shows that significant increase starts from Baghdad downward. This is due to the effect of the feedback from Tharthar depression toward Tigris River [90]. Where some of the Tigris flood flows is diverted at Samara Barrage to Tharthar depression which is highly saline (Figure 15), and then it is redirected for use in the river system with the salt washed from the depression. 


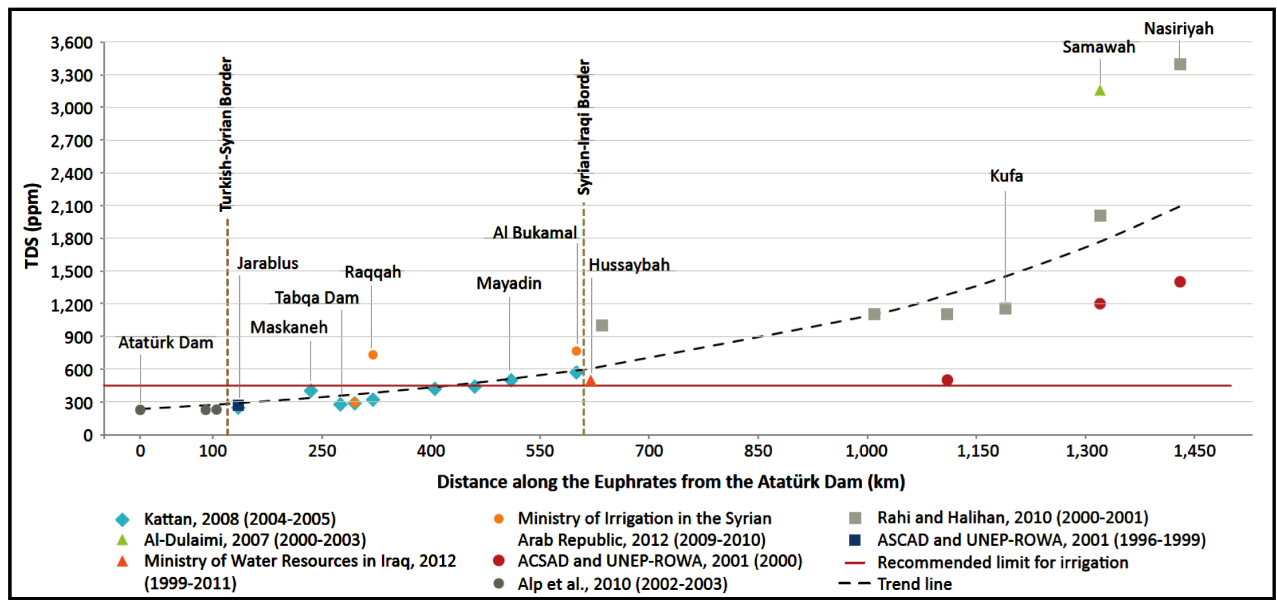

Figure 11. Salinity variation along Euphrates River since 1996 [2].

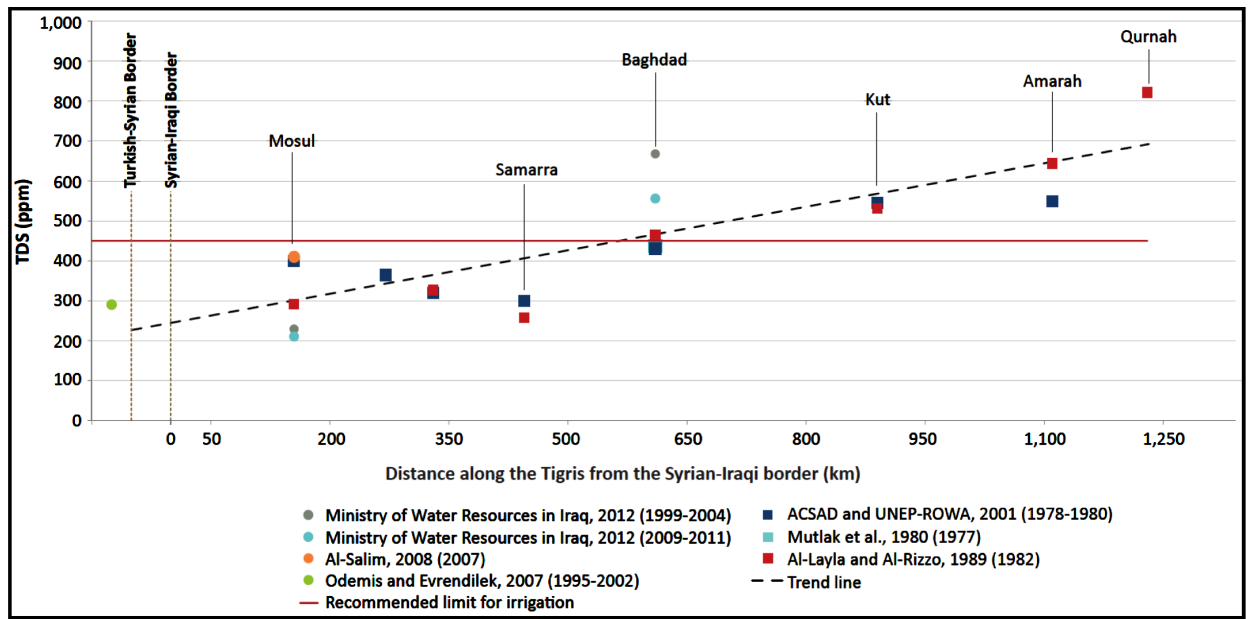

Figure 12. Salinity variation along Tigris River before 1983 and after 1995 [2].

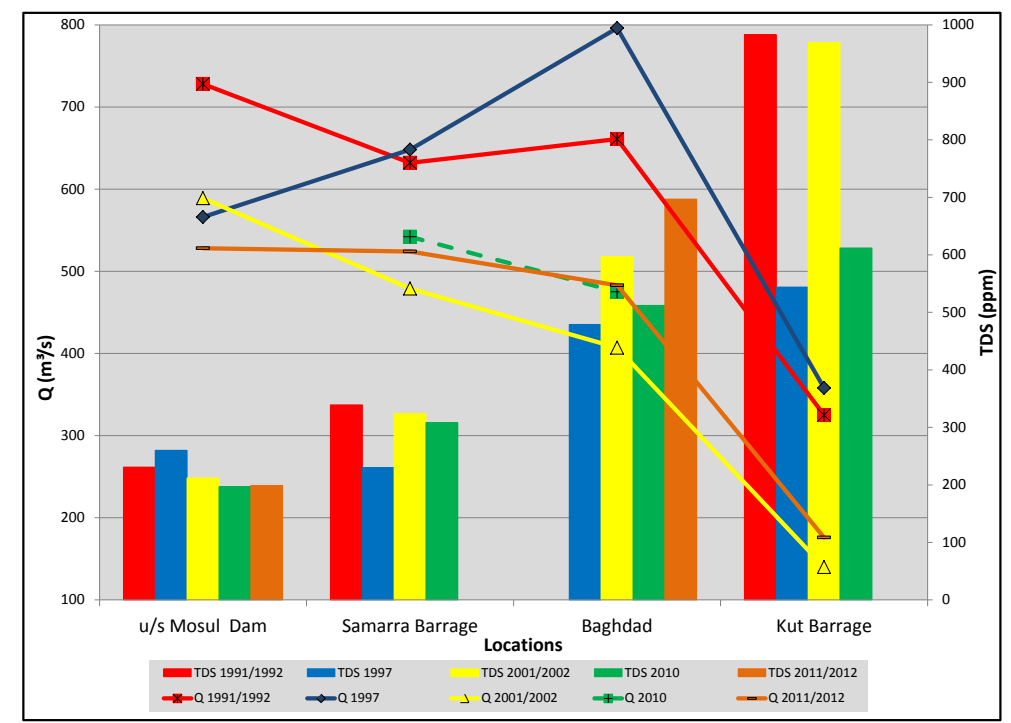

Figure 13. Variation of discharges (Q) and Total Dissolved Solids (TDS) along Tigris River inside Iraq. 


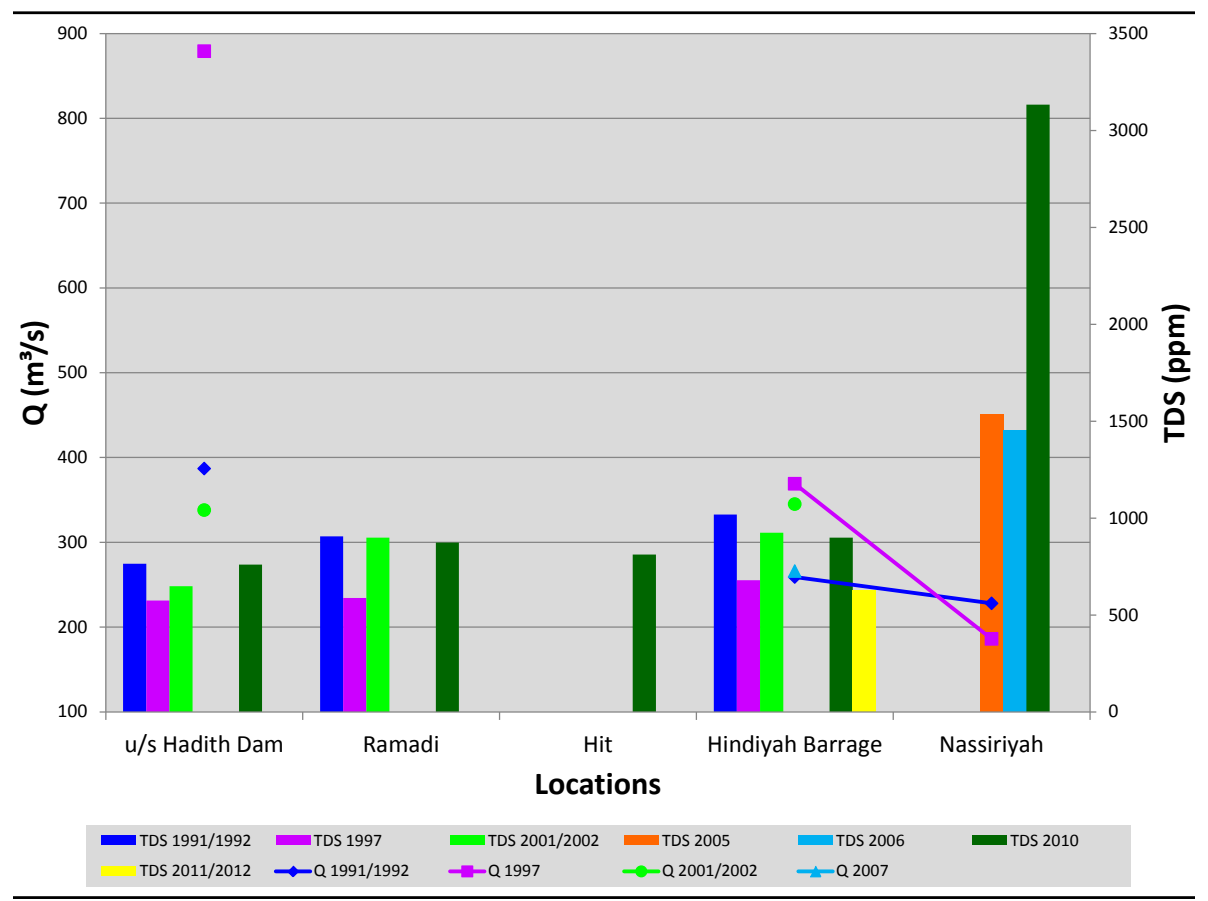

Figure 14. Variation of discharges (Q) and Total Dissolved Solids (TDS) along Euphrates River inside Iraq.

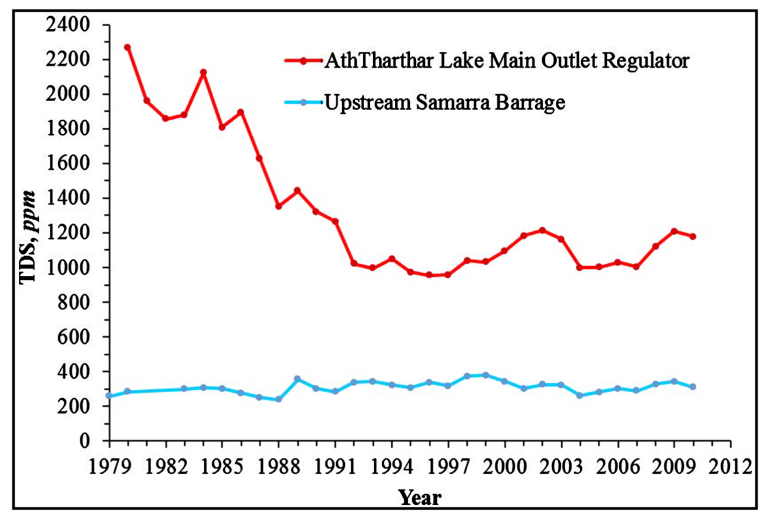

Figure 15. Total Dissolved Solids concentration at Samarra Barrage (the supplying point to Tharthar depression).

Recent estimates indicate that $4 \%$ of irrigated areas are severely saline, 50\% are of medium salinity and 20\% are slightly saline [91]. This forced the government to undertake a land rehabilitation program and a total of 700,000 ha were reclaimed. Later the situation deteriorated where recent estimates indicatethat $4 \%$ of irrigated areas are severely saline, $50 \%$ are of medium salinity and $20 \%$ ares lightly saline [87].

In addition to the above mentioned problems, declining water flow of the Tigris and Euphrates Rivers, the repeated frequency of drought [92], water quality degradation and increasing soil salinity mean that large areas of Iraq are facing serious problems of desertification. It is believed that at least $45 \%$ to $75 \%$ of the area of Iraq has been substantially affected by desertification [93] [94]. In addition, during the Gulf wars, huge number of palm trees were destroyed which originally were acting as natural barriers against the expansion of desertification. In view of the above, a large number of farmers and fishermen left their land and villages were deserted. The expansion of desert areas led to frequent sand or dust storms [54] [95]. Between 2007 and 2009, 40\% of cropland area experienced reduced crop coverage and 20,000 rural inhabitants left their homes (Figure 16 and Figure 17) [82]. 


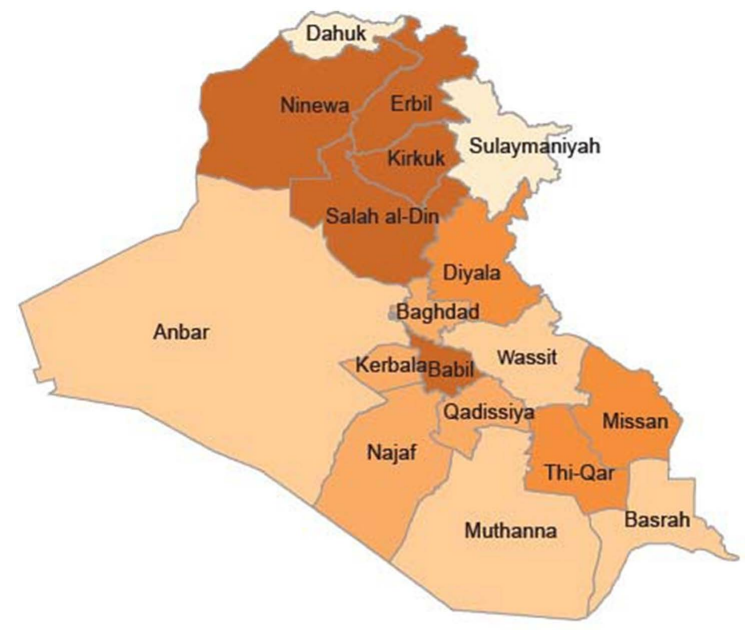

\begin{tabular}{|c|c|c|}
\hline $46 \%-56 \%$ & $31 \%-45 \%$ & $26 \%-30 \%$ \\
\hline $6 \%-25 \%$ & $4 \%-$ & \\
\hline
\end{tabular}

Source: FAO, IAU (2009)

Figure 16. Affected cropland/percentage of cropland [82].

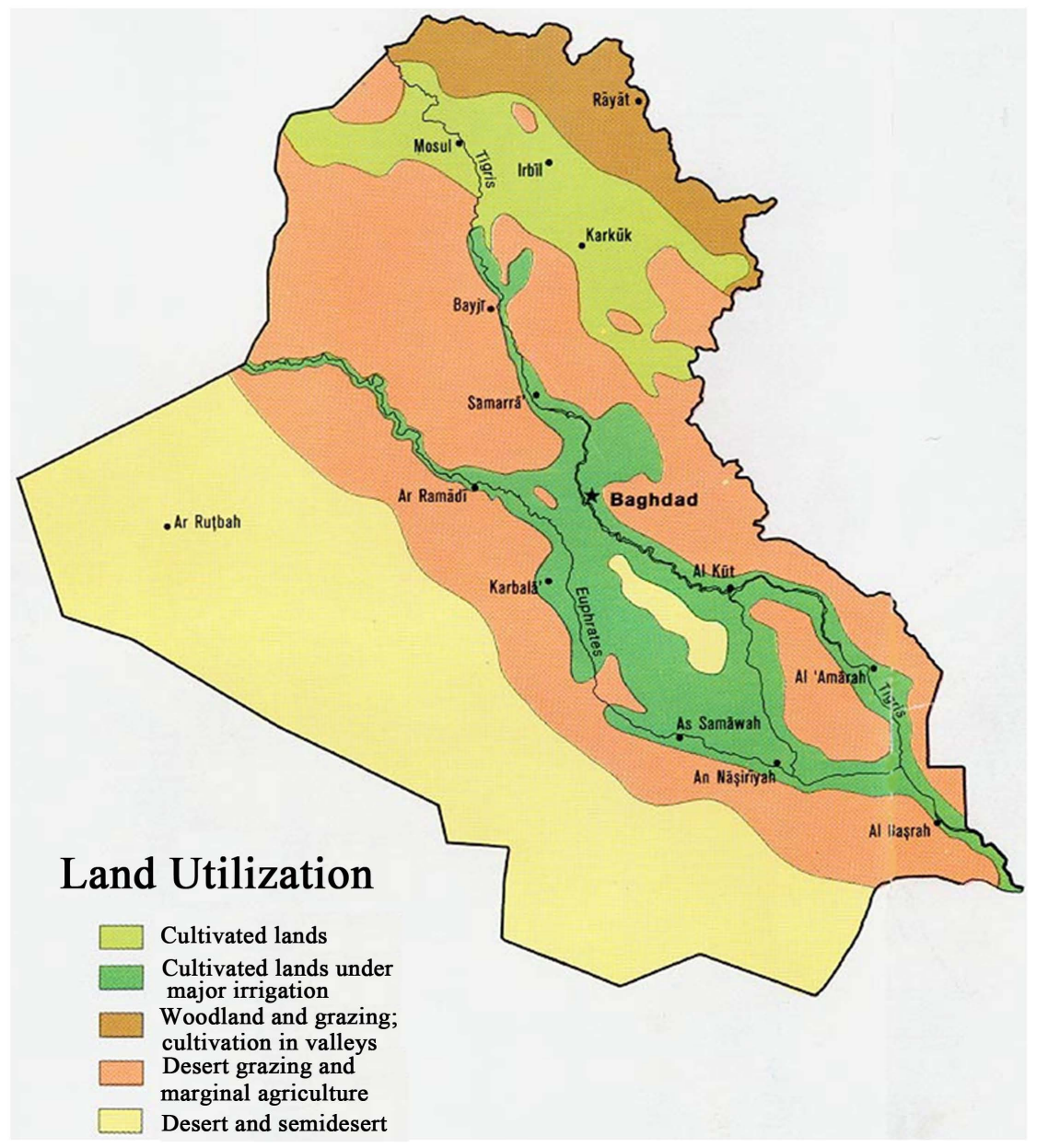

Figure 17. Land utilization in Iraq [96]. 
In view of the above, a large number of farmers and fishermen left their land and villages were deserted [37]. Between 2007 and 2009, 40\% of cropland area experienced reduced crop coverage and 20,000 rural inhabitants left their homes [82].

The industrial sector in Iraq deteriorated greatly after the UN sanctions in the 1990s. All most all the factories are not functioning. This includes paper and petrochemical industries in Basra, textile industries in Hilla and Wasit, food and vegetable oil industries in Baghdad and Karbala, pharmaceutical industries in Samara, construction industries Anbar and Najaf. No documents found stating the quantity of water consumed by these industries. Iraqi government is looking for external investments for rehabilitation of these industries [97]. In addition, the electricity generation in Iraq is facing great demand to increase the production by $24 \%$ in 2017 [85]. This means more installation of thermal power plants, which are the popular electricity sources in Iraq, to replenish electricity shortage which will induce s more water demand.

In addition to the above, the marshes area requires rehabilitation after it was dried during the past regime. Marsh lands, which are known as the Garden of Eden, cover an area about 15,000 - 20,000 $\mathrm{km}^{2}$ in the lower part of the Mesopotamian basin. Many agricultural projects were established on the dried lands at that time covering $1920 \mathrm{~km}^{2}$ distributed over three provinces. After the fall of the previous in 2003 and with the help of other countries and international organizations, a new program started to restore the Iraqi marshes [21]. It is believed that $70 \%-75 \%$ of the original areas of the marshes can be restored. Restoring the marshes requires $13 \mathrm{BCM}$ without improving the quality of water in the marshes and extra 5 BCM to improve it [75].

In summary, the overall water required to be 75 to 81 BCM [75]. In 2010, UN [20], estimated the overall water demand excluding restoring the marshes is about 73 BCM and the available water is about 59 - 75 BCM. If the situation remains as it is, the Iraqi water supplies will drop to 43 BCM by 2015 and to 17.61 BCM in 2025 and the demand is $77 \mathrm{BCM}$ or $66.85 \mathrm{BCM}$ at the least. According to the World Bank [64], the Iraqi water deficit in 2030 will reach 25.55 BCM (37\%) where the expected supply is 44 BCM only.

\section{Conclusions and Recommendations}

Iraq is facing water scarcity problem due to external and internal factors. External factors cannot be solved independently or in short term actions or planning like global climatic change and abusive water policies by riparian countries. In addition, these themes are to be addressed with regional and international cooperation.

In this context, there were number of agreements signed by riparian countries (especially Turkey, Syria and Iraq) for the water allocated. These agreements are well documented by ESCWA [2] and none of these had been put into practice for a long period of time. This is due to the fact that Turkey, considers the Euphrates and Tigris as Transboundary Rivers that falls under Turkish sovereignty as long as it is within its territory. Based on this, Turkey regards that it is not possible to share a commodity that constantly changes in quantity and quality, and in time and space due to the variable conditions of the hydrological cycle. While from Iraq and Syria point of view, these rivers are "international rivers" that should be treated as a shared entity by all riparian countries.

Long term expectations of the decrease of rainfall and temperature increase due to global climate change will inevitably reduce the quantity of the internal water resources and increase the desertification in Iraq which already reached $75 \%$. Turkish water projects (GAP, Ilisu...etc.) will control $80 \%$ of the Euphrates water and $47 \%$ of Tigris River flow to Iraq. At least, 696,000 ha of agricultural land will be abandoned influenced by these projects. The diversion of the water of Karun and Karkha tributaries inside the Iranian borders caused very high increase of the salinity in Shatt Al-Arab. It is believed these problems are to be solved by discussion and cooperation between riparian countries under the UN umbrella so that it takes a formal international cover. In addition, facing the expected climate change cannot be achieved unless the countries of the region act collectively.

About $85 \%$ of water withdrawal water in Iraq is consumed for agriculture. Where, only 1.9 million ha out of 4 million ha of arable land are cultivated in recent years. Even with the degradation in the productivity of the industrial sector, the hydropower consumption including the evaporation from reservoirs reaches $10 \mathrm{BCM} / \mathrm{annum}$. A plan to reduce the domestic consumption from 350 to 200 litre/capita/day is proposed parallel with other plans to supply potable water to $91 \%$ of the population by 2015 .

Internal problems and related issues of water scarcity can be solved independently in relatively short period of time. These are related to mismanagement of water resources inside Iraq, such as water losses in the distribution networks, overuse of water by inefficient irrigation systems, pollute water resources by sewage feedback, increase water salinity...etc. Iraqi government is to adopt water demand management instead of water supply management policy. 
Iraq suffers from many problems in its infrastructures, such as those related to water losses through its water distribution networks, water overuse in old irrigation schemes, and pollution of fresh water sources by back water from irrigation and sanitation. The efficiency of the distribution network is very poor (32\%) and it is deteriorating with time. Quality of drinking water does not meet WHO standards or Iraqi national water quality standards and the high contaminated leaked sewage water threatens potable water networks. The estimated effluent that discharged untreated directly to the rivers is over $0.5 \mathrm{MCM} /$ day.

The expansion of drainage of irrigated lands in Turkey and Syria will cause a further deterioration in the water quality of the rivers. The TDS level of Euphrates River at Syrian-Iraqi borders is $600 \mathrm{mg} / \mathrm{l}$ which is already higher that the recommended level for irrigation and increases to more than $1200 \mathrm{mg} / \mathrm{l}$ (as minimum) downstream at Samawah. Tigris River is relatively better than Euphrates at the borders, but the salinity increases significantly starting from Baghdad downstream by the influence of the feedback from Tharthar depression which is highly saline. The situation is worse on Diyala River where its TDS level reaches $3705 \mathrm{mg} / \mathrm{l}$.

It had been noticed by various researchers and organizations that the problem is becoming more alarming with time where the gap between supply and demand is increasing. The supply of Tigris and Euphrates Rivers will be 43 and 17.61 BCM in 2015 and 2025 respectively while the demand is estimated to be between 66.8 to 77 BCM respectively. In addition to all of this, it had been reported that Tigris and Euphrates discharges will continue to decrease with time and they will be completely dry by 2040 .

The following recommendations are believed to be able to help to overcome the water shortage problem in Iraq:

\section{A) Strategic Water Management Plan}

There is a great need for an integrated long term "National Water Master Plan" being designed and put in practice immediately. This plan should be a long term plan for at least 30 years. All authorities concerned should participate (e.g. Ministry of Water Resources, Ministry of Municipality and Public Work, Ministry of Agriculture, Water Resources staff at Universities, private sector, NGO's and representatives of regional and International organizations concerned) in this national plan. Water demand management is believed to be the backbone of such a plan. It should also consider the following:

- Rehabilitation of infrastructure which should cover water treatment plants, power plants as well as pumping stations.

- Public awareness program is vital so that all the people appreciate the seriousness of the problem they are facing.

- Defining institutional agenda that includes employment and training.

- Supply and demand should be considered. In this context new non-conventional water resources (water harvesting, treated waste water) are to be used.

- New irrigation techniques should be a priority also (e.g. sprinkler and drip irrigation).

- Private sector is to be enhanced to be involved in the investment.

- Inter-ministerial coordination is very important. This will save time, effort and money. More decentralization including budget in irrigation, water supply and sanitation sectors are to be practiced.

\section{B) Irrigation and Agriculture}

- The most efficient irrigation techniques that is suitable for the local conditions of soil, water availability and quality, crops ... etc. should be considered. Traditional irrigation techniques should be abandoned because they cause waste of water. Drip irrigation is convenient for orchards using salty water while sprinkler irrigation is suitable for grains and both of them are more conservative than surface irrigation.

- Maintaining and developing the conveying systems to reduce the losses and increase conveying efficiency. Closed conduits are to be considered as conveying system that reduces evaporation losses and infiltration losses. It is also conservative in land use and protects irrigation water from contact with saline water table.

- Improving the drainage systems of cultivated lands to improve soil leaching and reduce soil salinity. Also the most effective modern drainage techniques such as perforated pipe drainage system in collecting and FITO treatment in treating drainage water should be considered. Return of drainage water to the rivers should be avoided and drainage projects are to be implemented (like the main outfall drain in the areas laying outside the service zone of this project).

- Reducing the use of chemical fertilizers and pesticides that can decrease the water quality when back irrigation water discharges to the rivers.

- Using FITO treatment with drainage water and sewage water to reuse it in restoring the marshes as well as the available fresh water. 
- Institutions should reflect decentralization, autonomy and farmer empowerment.

- Enhance private investment in the agricultural sector.

- Public awareness program for farmers to use new suitable techniques in irrigation (drip irrigation and sprinkler irrigation).

- Partially built dams should be completed and measure is to be taken to build the suggested dams and irrigation projects. This will increase the storage capacity of dams about $27 \mathrm{~km}^{3}$.

\section{C) Water Supply and Sanitation}

- Efficiency of distribution networks of drinking water specially diversion and supply down to the point of use which is most cost effective should be improved.

- Sewage networks leakages should be repaired and their efficiencies improved to prevent any source of pollution from these networks.

- New efficient projects should be put in practice to prevent water losses and pollution.

- Operation and maintenance activities are to be improved e.g. using ICT.

- New sewerage systems are to be implemented in areas that are not serviced. The sewage water is to be conveyed to the sewage treatment plants to reduce the pollution of groundwater from the leakage from old septic tanks.

- Installing new sewage treatment plants to satisfy the increased consumption of domestic sector. Membrane bioreactor technology can be used in these new treatment plants to reuse the treated water.

\section{D) Research and Development}

- A comprehensive data bank should be established which includes reliable climatological, hydrological, geological, environmental and soil data to be used by researchers and decision makers.

- Conducting research to import new suitable technologies in water resources and agriculture which suites Iraq environment.

- Non-conventional methods to augments water recourses are to be used. We believe that water harvesting techniques can be very effective and are relative cheap cost wise as well as treated waste water which can be used for special kind of plants.

- Training programs for technicians, engineers and decision makers about up to date technologies are very important.

- Execute pioneer projects which help in augmenting water resources, developing land productivity, minimizing water use and consumption.

- Setting the outlines of public awareness programs both for water use and agricultural activities. Such a program should start at primary schools onward.

- Universities and institutes should set special courses in arid region hydrology.

- Awarding of prizes for new innovations, pioneer researches and smart ideas in water resources and their management.

- Groundwater resources are still not exhausted, big efforts should spend to manage prudent using of this source and protect it from all kinds of pollution.

E) Regional Cooperation and Coordination:

- Defining institutional and technical needs for such cooperation.

- Cooperation on trans-boundary resources. Iraq, Turkey, Iran and Syria are to coordinate their efforts to reach reasonable agreements with riparian countries on water quotas under the UN umbrella.

- UN organizations (e.g. UNEP, UNDP, UNESCO etc.) and International institutions and organizations (FAO, WMO etc.) and universities should be asked to give their experience in this matter.

- Cooperation with other countries, organizations and companies in developed countries to help in giving advice for successful patterns of water management to get benefit from their experiences.

\section{Acknowledgements}

The research presented has been financially supported by Luleå University of Technology, Sweden and by "Swedish Hydropower Centre-SVC" established by the Swedish Energy Agency, Elforsk and Svenska Kraftnät together with Luleå University of Technology, The Royal Institute of Technology, Chalmers University of Technology and Uppsala University. Their support is highly appreciated. The Iraqi Ministry of Water Resources gratefully helped the authors to conduct this research. 


\section{References}

[1] Al-Ansari, N.A. (2013) Management of Water Resources in Iraq: Perspectives and Prognoses. Journal of Engineering, 5, 667-668. http://dx.doi.org/10.4236/eng.2013.58080

[2] ESCWA (Economic and Social Commission for Western Asia) (2013) Inventory of Shared Water Resources in Western Asia. SalimDabbous Printing Co., Beirut, 626 p.

[3] Roger, P. and Lydon, P. (1994) Water in the Arab World. Harvard University Press, Massachusetts.

[4] Biswas, A.K. (1994) International Waters of the Middle East-From Euphrates, Tigris to Nile. Oxford University Press, Bombay.

[5] Allan, T. (2001) The Middle East Water Question. I.B.Tauris Publishers, London.

[6] Al-Ansari, N. (1998) Water Resources in the Arab Countries: Problems and Possible Solutions. UNESCO International Conference on World Water Resources at the Beginning of the 21st Century, Paris, 3-6 June 1998, 367-376.

[7] Cherfane, C.C. and Kim, S.E. (2012) Arab Region and Western Asia, UNESCWA. In: Managing Water under Uncertainty and Risk, UN World Water Development Report 4, Chapter 33.

[8] Barr, J., Grego, S., Hassan, E., Niasse, M., Rast, W. and Talafré, J. (2012) Regional Challenges, Global Impacts. In: Managing Water under Uncertainty and Risk, UN World Water Development Report 4, Chapter 7.

[9] Perry, C.J. and Bucknall, J. (2009) Water Resource Assessment in the Arab World: New Analytical Tools for New Challenges. In: Jagannathan, N.J., Mohamed, A.S. and Kremer, A., Eds., Water in the Arab World: Managment Perspectives and Innovations, World Bank, Middle East and North Africa Region, Washington, The World Express, 97-118.

[10] Hiniker, M. (1999) Sustainable Solutions to Water Conflicts in the Jordan Valley. Green Cross Internation, Geneva.

[11] Sadik, A.K. and Barghouti, S. (1994) The Water Problems of the Arab World: Management of Scarce Water Resources. In: Rogers, P. and Lydon, P., Eds., Water in the Arab World, Harvard University Press, Cambridge, Massachusetts, 4-37.

[12] Postel, S. (1992) Last Oasis: Facing Water Scarcity. Worldwatch Institute WW Norton \& Co, New York.

[13] Charrier, B. and Curtin, F. (2007) A Vital Paradigm Shift to Maintain Habitability in the Middle East: The Integrated Management of International Watercourses. In: Water for Peace in the Middle East and Southern Africa, Green Cross International, Geneva, 11-1.

[14] Bazzaz, F. (1993) Global Climatic Changes and Its Consequences for Water Availability in the Arab World. In: Roger, R. and Lydon, P., Eds., Water in the Arab Word: Perspectives and Prognoses, Harvard University, Cambridge, 243252.

[15] Al-Ansari, N.A., Salameh, E. and Al-Omari, I. (1999) Analysis of Rainfall in the Badia Region, Jordan. Al al-Bayt University Research Paper No.1, Mafraq, 66 p.

[16] Hamdy, A. (2013) Water Crisis and Food Security in the Arab World: The Future Challenges. http://gwpmed.org/files/IWRM-Libya/Atef\%20Hamdy\%20AWC.pdf

[17] Chenoweth, J., Hadjinicolaou, P., Bruggeman, A., Lelieveld, J., Levin, Z., Lange, M., Xoplaki, E. and Hadjikakou, M. (2011) Impact of Climate Change on the Water Resources of the Eastern Mediterranean and Middle East Region: Modeled 21st Century Changes and Implications. Water Resources Research, 47, W06506, 1-18.

[18] Voss, K., Famiglietti, J., Lo, M., de Linage, C., Rodell, M. and Swenson, S. (2013) Groundwater Depletion in the Middle East from GRACE with Implications for Transboundary Water Management in the Tigris-Euphrates-Western Iran Region. Water Resources Research, 49, 904-914. http://dx.doi.org/10.1002/wrcr.20078

[19] Nimah, M.N. (2008) Water Resources (2008) Report of the Arab Forum for Environment and Development. In: Tolba, M.K. and Saab, N.W., Eds., Arab Environment and Future Challenges, Chapter 5, 63-74, Arab Forum for Environment and Development, Beirut, Lebanon.

[20] UN (2010) Water Resources Management White Paper. United Nations Assistance Mission for Iraq, United Nations Country Team in Iraq, 20 p. http://iq.one.un.org/documents/100/white\%20paper-eng_Small.pdf

[21] Al-Ansari, N.A., Knutsson, S. and Ali, A. (2012) Restoring the Garden of Eden, Iraq. Journal of Earth Sciences and Geotechnical Engineering, 2, 53-88.

[22] Al-Ansari, N.A. and Knutsson, S. (2011) Toward Prudent Management of Water Resources in Iraq. Journal of Advanced Science and Engineering Research, 1, 53-67.

[23] Wikipedia (2014) Tigris-Euphrates River System. http://en.wikipedia.org/wiki/Tigris\%E2\%80\%93Euphrates_river_system

[24] Al-Ansari, N.A. (1979) Principles of Hydrogeology. Coll. of Science Press, Baghdad (In Arabic). 
[25] Al-Sayyab, A., Al-Ansari, N.A., Al-Rawi, D., Al-Jassim, J., Al-Omari, F. and Al-Shaikh, Z. (1982) Geology of Iraq. Mosul University Press, Iraq, 280 (In Arabic).

[26] Al-Ansari, N.A., Assaid, H.I. and Salim, V.N. (1981) Water Resources in Iraq. Journal of the Geological Society, 15, 35-42.

[27] Al-Ansari, N.A., Jassim, M.D., Thijeel, A., Abbas, H., Jawad, S.B. and Ahmad, A. (1990) Possibility of Using Western Desert for Agricultural Purposes. Ministry of Agricultural and Irrigation, Internal Report, 14 p.

[28] Al-Ansari, N.A., Dhari, M., Assad, N., Al-Shama, A. and Al-Jubori, S. (1993) Agricultural Use of Deserts Using Ground Water. Journal of Water Research, 12, 113-124.

[29] Al-Ansari, N.A. and Al-Shama, A. (1995) Long Term Utilization of Ground Water in Liefiya-Lusuf Area, Western Desert. Iraqi Science Journal, 36, 282-313.

[30] Al-Ansari, N.A., Rushdi, B. and AL-Shamma, A. (1995) Utilization of Ground Water for Agricultural Activities, South Nakhaib Area, Western Desert (IRAQ). International Conference on Water Resources Management in Arid Regions, Sultanate of Oman, 450-456.

[31] Alsam, S., Jassim, S.Z. and Hanna, F. (1990) Water Balance of Iraq: Stage 2, Geological and Hydrogeological Conditions. Report, Ministry of Irrigation, Iraq.

[32] Krasny, J., Alsam, S. and Jassim, S.Z. (2006) Hydrogeology. In: Geology of Iraq, 1st Edition, Dolin, Prague and Moravian Museum, Prague.

[33] AFED (Arab Forum for Environment and Development) (2009) Impact of Climate Change on Arab Countries. http://www.afedonline.org

[34] IPCC (Intergovernmental Panel on Climate Change) (2007) Climate Change 2007: Climate Change Impacts, Adaptation and Vulnerability. Cambridge University Press, Geneva.

[35] WRI (World Resources Institute) (2002) Drylands, People, and Ecosystem Goods and Services: A Web-Based GeoSpatial Analysis. http://www.wri.org

[36] Al-Ansari, N.A., Abdellatif, M., Ezeelden, M., Ali, S. and Knutsson, S. (2014) Climate Change and Future Long Term Trends of Rainfall at North-eastern Part of Iraq. Journal of Civil Engineering and Architecture, 8, 790-805.

[37] Al-Ansari, N.A., Abdellatif, M., Ali, S. and Knutsson, S. (2014) Long Term Effect of Climate Change on Rainfall in Northwest Iraq. Central European Journal of Engineering, 4, 250-263.

[38] Al-Ansari, N.A., Abdellatif, M., Al-Khateeb, M. and Knutsson, S. (2014) Desertification and Future Rainfall Trends north Iraq. 8th Edition of the International Scientific Congress of GIS and Geospace Applications Geotunis, Tunis/ Hammamet, 2-6 April 2014.

[39] Al-Ansari, N.A., Abdellatif, M., Zakaria, S., Mustafa, Y. and Knutsson, S. (2014) Future Prospects for Macro Rainwater Harvesting (RWH) Technique in North East Iraq. Journal of Water Resource and Protection, 6, 403-420. http://dx.doi.org/10.4236/jwarp.2014.65041

[40] Zakaria, S., Al-Ansari, N. and Knutsson, S. (2013) Historical and Future Climatic Change Scenarios for Temperature and Rainfall for Iraq. Journal of Civil Engineering and Architecture, 7, 1574-1594.

[41] World Bank (2011) DorteVerner and M. Fatma El-Mallah (League of Arab States), Adaptation to a Changing Climate in the Arab Countries. MNA Flagship Report, Sustainable Development Department, Middle East and North Africa Region.

[42] IPCC (Intergovernmental Panel on Climate Change) (2001) Climate Change 2001: The Scientific Basis. Contribution of Working Group I to the IPCC. Third Assessment Report 2001, Cambridge University Press, Cambridge.

[43] Dasgupta, S., Laplante, B., Meisner, C. and Yan, J. (2007) The Impact of Sea Level Rise on Developing Countries: A Comparative Study. World Bank Policy Research Working Paper 4136.

[44] Arnell, N.W. (2004) Climate Change and Global Water Resources: SRES Scenarios and Socio-Economic Scenarios. Global Environmental Change, 14, 31-52. http://dx.doi.org/10.1016/j.gloenvcha.2003.10.006

[45] Oweis, T. and Hachum, A. (2004) Water Harvesting and Supplemental Irrigation for Improved Water Productivity of Dry Farming Systems in West Asia and North Africa. New Directions for a Diverse Planet. Proceedings of the 4th International Crop Science Congress, Brisbane, 26 September-1 October 2004. www.cropscience.org.au

[46] Medany, M. (2008) Impact of Climate Change on Arab Countries. Chapter 9. www.afedonline.org/afedreport/english/book9.pdf

[47] Food and Agriculture Organization (FAO) (2009) Irrigation in the Middle East Region in Figures- AQUASTAT Survey. 2008 Water Report 34, 2. http://www.fao.org/docrep/012/i0936e/i0936e00.htm

[48] Yahya, J.Q. (2002) Climate Change for the Semi-Mountainous Region in Iraq and Its Impact on the Productivity of Wheat and Barley. Unpublished Master Thesis, Department of Geography, University of Tikrit, College of Education, 
Tikrit.

[49] Wetherald, R.T. and Manabe, S. (2002) Simulation of Hydrologic Changes Associated with Global Warming. Journal of Geophysical Research, 107, 4379. http://dx.doi.org/10.1029/2001JD001195

[50] Karrou, M. (2002) Climatic Change and Drought Mitigation: Case of Morocco. The First Technical Workshop of the Mediterranean, Component of CLIMAGRI Project on Climate Change and Agriculture, Rome, 25-27 September 2002, $7 p$. http://www.semide.net/media_server/files/semide/topics/waterscarcity/background/climatic-change-and-drought-mitig ation-case-morocco/ws01 38.pdf

[51] Abbas, A. (2002) Drought Suppression Procedures for Dry Lands. The First Technical Workshop of the Mediterranean, Component of CLIMAGRI Project on Climate Change and Agriculture, Rome, 25-27 September 2002, 12p. http://www.docstoc.com/docs/32615805/DROUGHT-SUPPRESSION-PROCEDURES-FOR-DRY-LANDS-EXAMP LE-SALAMIA

[52] Mougou, R. and Mohsen, M. (2005) Hendi Zitoune Case Study: Agro Climatic Characterization and Evapotranspiration Evolution in Climate Change Conditions. Fourth Tunisian Semi-Annual Report. Contribution to the AIACC AF 90 North Africa Project: Assessment, Impacts, Adaptation, and Vulnerability to Climate Change on North Africa: Food and Water Resources.

[53] AL-Bayati, F.F. (2011) Climatic Conditions and Their Impact on the Geographical Distribution of the Dust Storms Empirical Study at Al-Anbar Province-Iraq. Anbar University, Journal for the Humanities, 1, 26-38.

[54] Sissakian, V., Al-Ansari, N.A. and Knutsson, V. (2013) Sand and Dust Storm Events in Iraq. Natural Science, 5, 1084-1094. http://dx.doi.org/10.4236/ns.2013.510133

[55] Elasha, B.O. (2010) Mapping of Climatic Change Threats and Human Development Impacts in the MENA Region. United Nations Development Programme, MENA Human Development Report (AHDR), Research Paper Series 2010. http://www.MENA-hdr.org/publications/other/ahdrps/paper02-en.pdf

[56] Milly, P.C.D., Dunne, K.A. and Vecchia, A.V. (2005) Global Patterns of Trends in Stream Flow and Water Availability in a Changing Climate. Nature, 438, 347-350. http://dx.doi.org/10.1038/nature04312

[57] Burleson, E. (2005) Equitable and Reasonable Use of Water within the Euphrates-Tigris River Basin. Environmental Law Institute, Washington.

http://www.internationalwaterlaw.org/bibliography/articles/general/BurlesonTigris-Euphrates.pdf

[58] Kamel, A., Sulaiman, S. and Mustaffa, S. (2013) Study of the Effects of Water Level Depression in Euphrates River on the Water Quality. Journal of Civil Engineering and Architecture, 7, 238-247.

[59] Ministry of Water Resources-Iraq (MWR) (2010) Annual Report. National Centre for Water Resources Management.

[60] Biedler, M. (2004) Hydropolitics of the Tigris-Euphrates River Basin with Implications for the European Union. Research Paper no. 1, Centre European de Reserche International et Strategique. http://www.ceris.be/fileadmin/library/Research\%20Papers/1\%20Hydropolitics\%20of\%20the\%20Tigris-Euphrates\%20 Rivers\%20Bassin\%20with\%20implantations\%20for\%20the\%20European\%20Union.pdf

[61] Alkanda, A., Freeman, S. and Placht, M. (2007) The Tigris-Euphrates River Basin: Mediating a Path towards Alnakhla. The Flecher School Journal for Issues Related to Southwest Asia and Islamic Civilization. http://fletcher.tufts.edu/AlNakhlah/Archives/ /media/Fletcher/Microsites/al\%20Nakhlah/archives/pdfs/placht-2.pdf

[62] GAP (2006) South-Eastern Anatolia Project: Latest Situation. http://www.gap.gov.tr/English/Genel/sdurum.pdf

[63] Unver, I. (1997) Southeastern Anatolia Project (GAP). International Journal of Water Resources Development, 13, 453-484. http://dx.doi.org/10.1080/07900629749575

[64] Shams, S. (2006) Water Conflict between Iraq and Turkey. Middle East News. http://www.mokarabat.com/m1091.htm

[65] Alnajaf News Net (2009) The GAP Project and Its Negative Implications on Iraq (in Arabic). http://www.arabo.com/links/,199,225,218,209,199,222/,197,218,225,199,227/45188.html

[66] Waterbury, J. (1993) Transboudary Water and the Challenge of International Cooperation in the Middle East. In: Roger, R. and Lydon, P., Eds., Water in the Arab Word: Perspectives and Prognoses, Harvard University, Cambridge, 39-64.

[67] Alsowdani, M. (2005) GAP Project and Its Economic Negative Implications on Syria and Iraq, in Al-Itehad News. http://www.alitthad.com/paper.php?name=News\&file=print\&sid=19030

[68] National Defense Magazine (2009) Turkish Israeli Partnership in GAP Southeastern Anatolian Project. Official Site of the Lebanese Army. http://www.lebarmy.gov.lb/article.asp?ln=ar\&id=2901

[69] Murakami, M. (1995) Managing Water for Peace in the Middle East: Alternative Strategies. United Nations University Press, Tokyo. http://archive.unu.edu/unupress/unupbooks/80858e/80858E04.htm

[70] Beaumont, P. (1995) Agricultural and Environmental Changes in the Upper Euphrates Catchment of Turkey and Syria 
and Their Political and Economic Implications. Applied Geography, 16, 137-157.

[71] Alyaseri, S. (2009) GAP Project: Dangerous Consequences on Life in Iraq. Official Site of Iraqi Council for Peace and Unity. http://www.marafea.org/paper.php?source=akbar\&mlf=copy\&sid=11556

[72] Robertson, C. (2009) Iraq Suffers as the Euphrates River Dwindles. The New York Times. July $13^{\text {th }}, 2009$. http://www.nytimes.com/2009/07/14/world/middleeast/14euphrates.html?_r=0

[73] Iraqi Civil Society Solidarity Initiative (2014) Ilisu Dam and Legal Considerations in Iraq. http://www.iraqicivilsociety.org/archives/2902

[74] Majeed, Y. (1993) The Central Regions: Problems and Perspectives. In: Roger, R. and Lydon, P., Eds., Water in the Arab Word: Perspectives and Prognoses, Harvard University, Cambridge, 101-120.

[75] World Bank (2006) Iraq: Country Water Resources, Assistance Strategy: Addressing Major Threats to People’s Livelihoods. Report no. 36297-IQ, 97 p.

[76] World Bank (2014) Country at a Glance: Iraq. http://data.worldbank.org/country/iraq

[77] Iraqi Ministry of Municipalities and Public Work (IMMPW) (2011) Water Demand and Supply in Iraq: Vision, Approach and Efforts, GD for Water. http://www.mmpw.gov.iq/

[78] Stockholm International Water Institute (SIWI) (2009) Water Resources in the Middle East. Background Report to Seminar on Water and Energy Linkages in the Middle East, 9.

[79] Ministry of Water Resources-Iraq (MWR) (2014) The Strategic Study for Iraqi Water Resources and Lands, in Arabic, http://www.mowr.gov.iq/?q=node/902

[80] Multiple Indicator Cluster Survey (MICS) (2007) IRAQ: Monitoring the Situation of Children and Women. Final Report. http://www.childinfo.org/files/MICS3_Iraq_FinalReport_2006_eng.pdf

[81] World Bank (2013) Food and Agriculture Organization, AQUASTAT, Renewable Internal.

[82] IAU (Inter-Agency Information and Analysis Unit) (2011) Water in Iraq Factsheet. http://www.iauiraq.org/documents/1319/Water\%20Fact\%20Sheet\%20March\%202011.pdf

[83] A Climate for Change (2012) Water Supply and Sanitation in Iraq. http://www.aclimateforchange.org/profiles/blogs/water-supply-and-sanitation-in-iraq

[84] Jawaheri, E.A. and Alsahmari, R.A. (2009) Water Problems of Iraq and Possible Solutions. Journal of Law and Politics, 2, 9-61.

[85] MoP (Ministry of Planning-Iraq) (2013) National Development Plan 2013-2017. Baghdad.

[86] Al-Ansari, N.A. (2005) Applied Surface Hydrology. Al al-Bayt University Publication, Mafraq (In Arabic).

[87] The Encyclopedia of Earth (2008) Water Profile of Iraq. http://www.eoearth.org/article/Water_profile_of_Iraq

[88] Ritzema, H. and Braun, H. (1994) Environmental Aspects of Drainage, Chapter 25. In: Environmental Drainage Principles and Applications, International Institute for Land Reclamation and Improvement (IILRI), Publication No. 16, 1041-1065.

[89] Merry, M. (1992) Iraq Builds “Third River” Project Despite No-Fly Zone and Embargo. Executive Intelligence Review, Washington, DC, 19, 8-10.

[90] Al-Shamari, H.M. (1994) Hydro Chemical Investigations of Tharthar Lake and Its Possible Effect on the Hydrochemistry of Euphrates River. M. Sc. Thesis, University of Baghdad, Baghdad (in Arabic).

[91] Consulting Engineering Bureau (CEB) (2011) Lakes Testing Study. College of Engineering, University of Baghdad, Baghdad.

[92] Ali, S.M., Qutaiba, A.S., Hussan, M. and Al-Azawi, F.W. (2013) Fluctuating Rainfall as One of the Important Cause for Desertification in Iraq. Journal of Environment and Earth Science, 3, 25-33.

[93] Raphaeli, N. (2009) Water Crisis in Iraq: The Growing Danger of Desertification, Investors Iraq, 23 July 2009 , no. 537. http://www.investorsiraq.com/showthread.php?132306-Water-Crisis-in-Iraq-The-Growing-Danger-of-Desertification

[94] Al-Saidi, A. and Al-Juaiali, S. (2013) The Economic Costs and Consequences of Desertification in IRAQ. Global Journal of Political Science and Administration, 1, 40-45.

[95] UN-Iraq (2011) Sand and Sand Storm Fact Sheet. http://reliefweb.int/sites/reliefweb.int/files/resources/SDS\%20Fact\%20Sheet.pdf

[96] Food and Agriculture Organization (FAO) (2005) Country Profile: Land Use and Water Resources. http://www.fao.org/ag/agp/AGPC/doc/Counprof/Iraq/Iraq.html

[97] Ministry of Industry and Minerals-Iraq (MIM) (2008) Industrial Investment Opportunities in IRAQ. Investment Department, Baghdad, no. 537. http://www.investorsiraq.com/showthread.php?132306-Water-Crisis-in-Iraq-The-Growing-Danger-of-Desertification 
Scientific Research Publishing (SCIRP) is one of the largest Open Access journal publishers. It is currently publishing more than 200 open access, online, peer-reviewed journals covering a wide range of academic disciplines. SCIRP serves the worldwide academic communities and contributes to the progress and application of science with its publication.

Other selected journals from SCIRP are listed as below. Submit your manuscript to us via either submit@scirp.org or Online Submission Portal.
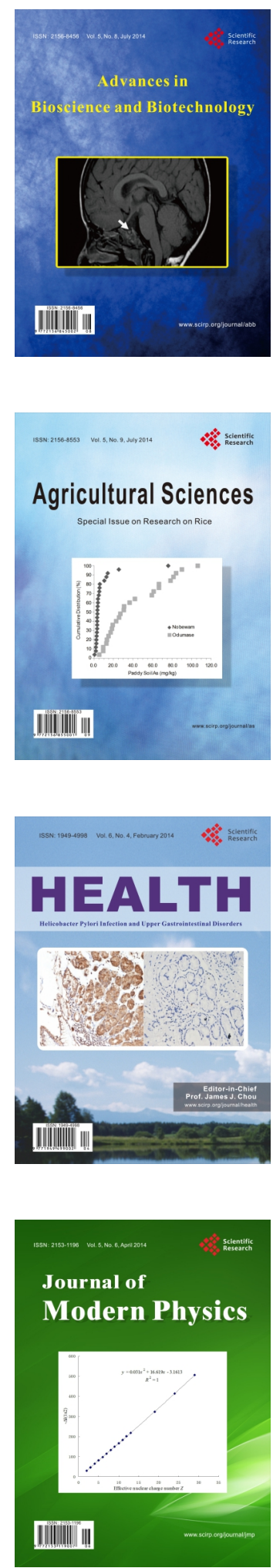
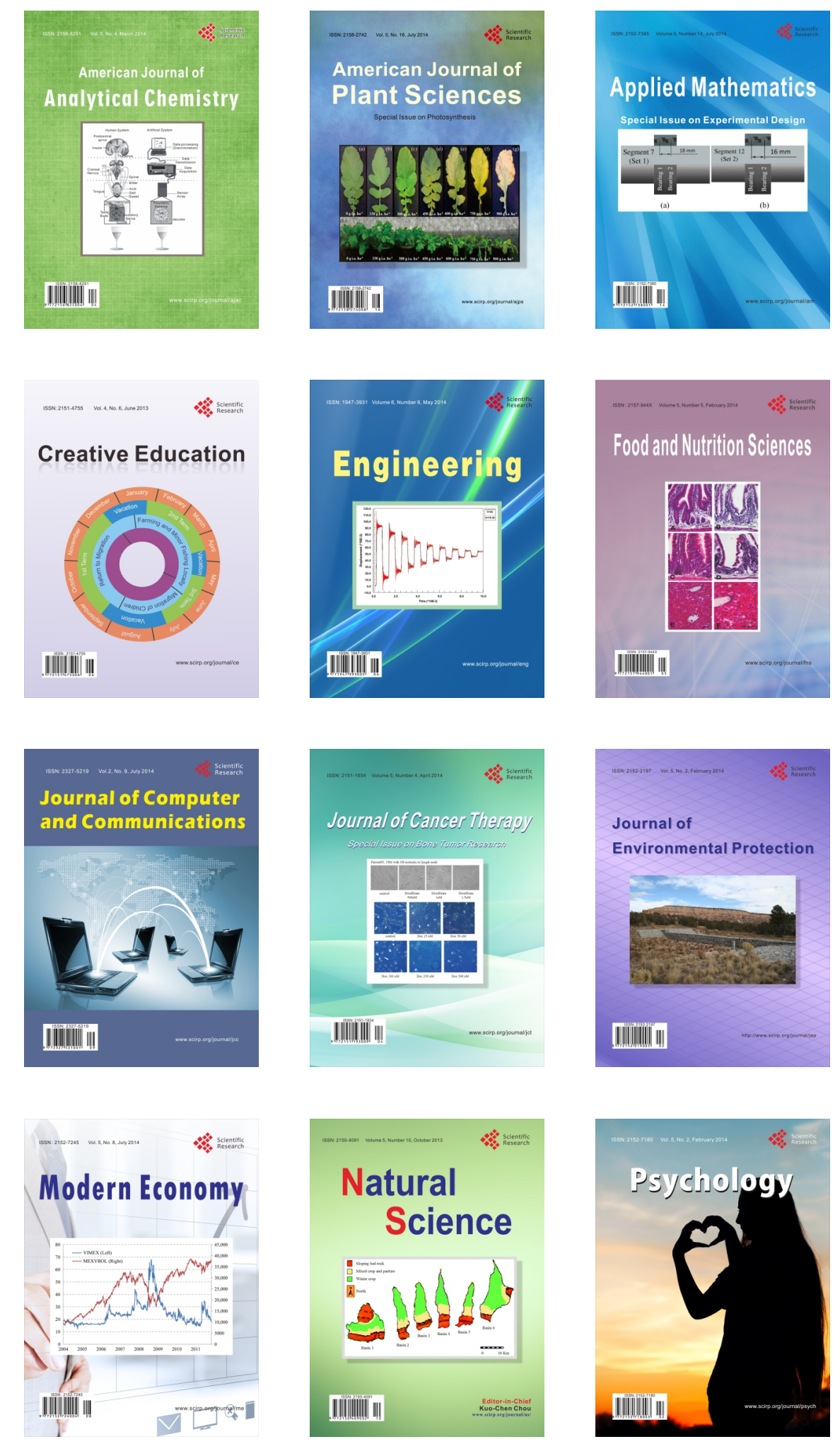